\title{
Standards and Agro-Food Exports from Developing Countries: Rebalancing the Debate
}

\author{
Steven Jaffee and Spencer Henson ${ }^{1}$
}

\author{
Contacts: sjaffee@worldbank.org shenson@uoguelph.ca
}

\begin{abstract}
The proliferation and increased stringency of food safety and agricultural health standards is a source of concern among many developing countries. These standards are perceived as a barrier to the continued success of their exports of high-value agro-food products (including fish, horticultural, and other products), either because these countries lack the technical and administrative capacities needed for compliance or because these standards can be applied in a discriminatory or protectionist manner. This paper draws on available literature and work in progress to examine the underlying evidence related to the changing standards environment and its impact on existing and potential developing country exporters of high-value agricultural and food products. The evidence presented in this paper, although only partial, suggests that the picture for developing countries as a whole is not necessarily problematic and certainly is less pessimistic than the mainstream 'standards-as-barriers' perspective. Indeed, rising standards serve to accentuate underlying supply chain strengths and weaknesses and thus impact differently on the competitive position of individual countries and distinct market participants. Some countries and/or industries are even using high quality and safety standards to successfully (re-)position themselves in competitive global markets. This emphasizes the importance of considering the impacts of food safety and agricultural health measures within the context of wider capacity constraints and underlying supply chain trends and drivers. The key question for developing countries is how to exploit their strengths and overcome their weaknesses such that they are gainers rather than losers in the emerging commercial and regulatory context.
\end{abstract}

Keywords: SPS standards; capacity-building; compliance costs; high-value agro-food trade

World Bank Policy Research Working Paper 3348, June 2004

The Policy Research Working Paper Series disseminates the findings of work in progress to encourage the exchange of ideas about development issues. An objective of the series is to get the findings out quickly, even if the presentations are less than fully polished. The papers carry the names of the authors and should be cited accordingly. The findings, interpretations, and conclusions expressed in this paper are entirely those of the authors. They do not necessarily represent the view of the World Bank, its Executive Directors, or the countries they represent. Policy Research Working Papers are available online at http://econ.worldbank.org.

\footnotetext{
${ }^{1}$ Steve Jaffee is Senior Economist in the World Bank's International Trade Department. Spencer Henson is Associate Professor in the Department of Agricultural Economics and Business, University of Guelph, Canada.
} 


\section{INTRODUCTION}

This paper explores the impact that food safety and agricultural health standards are having on the performance of developing countries with respect to agricultural and food product exports. It recognizes that standards can, and indeed do, act to impede exports, either because explicit bans are placed on imports of particular products or the costs of compliance with stringent requirements diminish export competitiveness. However, in an attempt to 'rebalance' the dialogue in this area, it suggests that the proliferation and increased stringency of food safety and agricultural health standards are creating a new landscape that, in certain circumstances, can be a basis for the competitive repositioning and enhanced export performance of developing countries. Thus, standards can be a source of competitive advantage, or at least developing countries may have little choice but to respond as standards evolve and should do so in a manner that is to their best strategic advantage. Key to this, however, is the ability of developing countries to upgrade capacity and make necessary adjustments in the structure and operation of their supply chains. Thus, from the outset, the chapter purposefully explores the nature of this new standards landscape and the related capacity requirements, before moving on to a discussion of the impacts on trade. Further, in discussing these trade effects it adopts not only the traditional approach using quantitative measures of changes in trade that are related to the evolution of standards, but presents a number of illustrative case studies that relate losses or gains in trade to food safety and agricultural health requirements within the context of wider supply chain challenges.

\section{STANDARDS: BARRIER or CATALYST?}

Expanding global trade in perishable agricultural products and high-value foods has served to highlight the extent to which national standards for food safety and animal and plant health diverge, as well as the differential capacities of public authorities and commercial supply chains to manage the potential risks associated with trade in these products. For many higher-value foods, including fruits and vegetables, fish, beef, poultry and herbs and spices, the challenges of international competitiveness have moved well beyond price and basic quality parameters to greater emphasis on food safety and agricultural health concerns. ${ }^{2}$ Across this range of products there is increasing attention to the risks associated, for example, with microbial pathogens, residues from pesticides, veterinary medicines or other agricultural inputs and environmental or naturally-occurring toxins. In turn, there is greater scrutiny of the production or processing techniques employed along these supply chains (Buzby and Unnevehr 2003).

There are various reasons why food safety and agricultural health standards, commonly referred to as sanitary and phytosanitary (SPS) measures within the context of the World Trade Organization (WTO), differ between countries (Unnevehr 2003 and Henson 2004). First, there are significant differences in tastes, diets, income levels and perceptions that influence the tolerance of populations toward these risks. Differences in climate and in the available technology (from refrigeration through to irradiation) affect the incidence of different food safety and agricultural health hazards. Standards reflect the feasibility of implementation, which itself

\footnotetext{
${ }^{2}$ For the more 'traditional' agro-food export commodities of developing countries, such as beverage crops, fiber crops, tobacco and sugar, international trade is still largely governed by price and basic quality parameters and by traditional forms of trade protection/preferences.
} 
is influenced by legal and industry structures as well as available technical, scientific, administrative and financial resources. Some food safety risks, for example, tend to be greater in developing countries due to weaknesses in physical infrastructure (for example standards of sanitation and access to potable water) and the higher incidence of certain infectious diseases. Further, tropical or sub-tropical climatic conditions may be more conducive to the spread of certain pests and diseases that pose risks to human, animal and/or plant health.

The intrinsic risks associated with the production, transformation and sale of high-value and perishable food products, combined with different standards and institutional capabilities, can pose major challenges for international trade in these products. This is even more so because the landscape for food safety and agricultural health standards is rapidly changing. Over the past decade there has been greatly increased public awareness and concern about food safety within high-income developed countries in the wake of a series of highly publicized food scares or scandals. ${ }^{3}$ In some countries, these events have shaken the underlying confidence of consumers in national or regional systems of food safety regulation. In response, there have been significant institutional changes in food safety oversight and reform of pertinent laws and regulations. For long-held concerns (for example the potential environmental and health impacts of pesticides), there has been a tightening of many standards in industrialized and other countries. In addition, new standards are being applied to address previously unknown or unregulated hazards. ${ }^{4}$

In parallel with these changes in official standards and public oversight, have been accelerated moves by the private sector to address food safety risks and otherwise address the concerns and preferences of consumers and civil society organizations. Much of the motivation behind this trend has been the mitigation of reputational and/or commercial risks, while in some product lines and industries these moves have also been part of commercial strategies of differentiation. The ensuing result has been a growing plethora of private 'codes of practice', standards and other forms of supply chain governance. While these efforts have been especially prominent amongst major food retailers, food manufacturers and restaurant chains in industrialized countries, systems of private food safety governance are also being applied more widely in middle-income and some low-income countries, in part through the investments undertaken by multinational supermarket or restaurant chains and competitive responses by local firms (Reardon and Berdegue 2002). In addition, new food safety standards in industrialized countries are serving to shape the expectations of developing country consumers, especially those with higher incomes and in urban areas.

The proliferation and enhanced stringency of food safety and agricultural health standards is a source of concern among many developing countries and those promoting the increased integration of these countries into the world trading system. Reflecting wider changes in the trade regime for various agricultural and food products, there is a presumption that food safety and agricultural health measures can (and will) be used as a protectionist tool, providing 'scientific' justifications for prohibiting imports of certain products altogether, or discriminating against imports by applying higher standards and/or more rigorous regulatory oversight than on

\footnotetext{
${ }^{3}$ A few examples include Bovine Spongiform Encephalopathy (BSE) in beef in the UK, E. coli in hamburgers in the United States, and dioxins in animal feed in Belgium.

${ }^{4}$ For example BSE, Genetically-Modified Organisms (GMOs), environmental contaminants (such as dioxins and $\mathrm{PCBs}$ ) and naturally-occurring toxins (such as Ochratoxins).
} 
domestic suppliers. Even if standards are not intentionally used to discriminate against imports, there is concern that their growing complexity and lack of harmonization between countries could still impede the trading efforts of developing countries.

There is also concern that many developing countries simply lack the administrative, technical and scientific capacities to comply with emerging requirements, presenting potentially insurmountable barriers in the short or medium-term. And, the investment and recurrent 'costs of compliance' could undermine the competitive position of developing countries or otherwise compress the profitability of high-value food exports. The combined effects of institutional weaknesses and rising compliance costs could, it is argued, contribute to the further marginalization of weaker economic players at various levels, including small/poor countries, small and medium-sized businesses and small-holder farmers.

An alternative and less pessimistic view emphasizes the potential opportunities provided by the evolving standards environment and the likelihood that certain developing countries can utilize such opportunities to their competitive advantage. From this perspective, many of the emerging public and private standards are viewed as a necessary bridge between increasingly demanding consumer requirements and the participation of distant (and international) suppliers. Many of these standards provide a common language within the supply chain and promote the confidence for consumers in food product safety. ${ }^{5}$ Without that confidence, the market for these products cannot be maintained, let alone increased, in turn jeopardizing international trade. ${ }^{6}$

From this "standards-as-catalyst" perspective, the challenge inherent in compliance with food safety and agricultural health standards may well provide a powerful incentive for the modernization of developing country export supply chains and give greater clarity to the necessary and appropriate management functions of government. Further, via increased attention to the spread and adoption of 'good practices' in agriculture and food manufacture, there may be spillovers into domestic food safety and agricultural health, to the benefit of the local population and domestic producers. Part of the costs of compliance could be considered necessary investments, while an array of foreseeable and unforeseeable benefits might arise from the adoption of different technologies or management systems. Rather than degrading the comparative advantage of developing countries, enhancement of capacity to meet stricter standards could, potentially, create new forms of competitive advantage. Hence, the process of standards compliance could conceivably provide the basis for a more sustainable and profitable trade over the long-term, albeit with some particular winners and losers. ${ }^{7}$

\footnotetext{
${ }^{5}$ The increased number and blend of product and process attributes now sought by consumers can be embodied in agreed standards, thus reducing transaction costs.

${ }^{6}$ The array of recent food scares and their enormous short or medium term impacts on consumer demand and international trade in beef and selected other livestock products fully attest to the importance of consumer confidence in food safety governance systems.

${ }^{7}$ Whilst this is currently the minority view of the impact of SPS measures on developing countries, there is an expanding catalogue of cases where countries have been able to exploit market opportunities because of their greater capacity to comply with food safety or animal health requirements. This may reflect 'natural' differences in the prominence of food safety or plant/animal disease problems, for example because of climatic conditions, or the success of efforts to enhance SPS control capacity.
} 
This rather crude dichotomy between 'standards as barriers' and 'standards as catalysts' suggests a complex reality in which close attention is needed to the specifics of particular markets, products and countries to understand how the changing food safety and agricultural health standards environment is providing challenges and opportunities for developing countries. Further, there is a need to understand the strategic options and patterns of performance of developing countries in meeting these challenges and their ability to exploit emerging opportunities. This paper draws upon the available literature and work in progress to comment on the underlying evidence related to the changing standards environment and its implications for both existing and potential developing country exporters of high-value agricultural and food products. The following sections provide a commentary on the varied concerns associated with standards and developing country trade, noting the availability of systematic or anecdotal evidence that supports or opposes prevailing claims and the assumptions on which they are based. The result is a varied picture, partially supporting both these opposing perspectives. In turn, this highlights the dangers of making overly generalized propositions and the need to differentiate analyses and strategies in relation to food safety and agricultural health standards and developing country trade. Subsequently, the paper re-visits some of these prominent themes through the lens of selected case studies.

\section{THE SPS AGREEMENT: AN END TO DISGUISE AND DISCRIMINATION?}

During the Uruguay Round of multilateral trade negotiations, agricultural exporters voiced concerns that SPS measures were sometimes being used to restrict foreign competition to domestic producers and that such protectionist measures would likely increase as more traditional trade barriers (such as tariffs and quotas) declined. The Agreement on the Application of Sanitary and Phytosanitary Measures (SPS Agreement) was negotiated in order to provide a set of multilateral rules that would both recognize the legitimate need of countries to adopt SPS measures and create a framework to reduce their trade distorting effects.

The SPS Agreement built upon the Standards Code, introduced in the 1947 General Agreement on Tariffs and Trade (GATT). It permitted measures that were 'necessary to protect human, animal or plant life and health', yet required regulators to: (1) base measures on a scientific risk assessment; (2) recognize that different measures can achieve equivalent safety outcomes; and (3) allow imports from distinct regions in an exporting country when presented with evidence of the absence or low incidence of pests or diseases. In addition, the Agreement encouraged (yet did not require) the adoption of international standards, making explicit reference to those of the Codex Alimentarius Commission (CAC) for food safety, the International Office of Epizootics (OIE) for animal health and the International Plant Protection Convention (IPPC) for plant health. Importantly, the Agreement protects the right of a country to choose its own 'appropriate level of protection', yet guides members to 'take into account the objective of minimizing negative trade effects.'

The SPS Agreement thus sets out broad ground rules for the legitimate application of food safety and agricultural health measures, many of which could affect international trade. Yet, the Agreement gives countries fairly broad latitude in setting and applying such measures. Scientific justification is called for wherever standards are deemed to not be based on established international standards. Yet, complications are inevitable given the wide range of areas for 
which no agreed international standards exist and given broad (and emerging) areas for which the state of scientific knowledge is incomplete. Hence, many of the controversies which have occurred surround the legitimacy and appropriateness of measures in the context of scientific uncertainty.

Important underlying objectives of the SPS Agreement are the minimization of the protectionist and unjustified discriminatory use of standards and promotion of greater transparency and harmonization. In both regards, the experience has been mixed. The difficulties encountered are probably less due to specific shortcomings of the SPS Agreement itself than the intrinsic complexities of the management of food safety and animal health protection and rapidly evolving markets for agricultural and food products. Further, it is evident that WTO Members vary widely, both in their understanding of the Agreement and their ability to take advantage of the rights and responsibilities it defines.

The SPS Agreement has not eradicated the differential application of standards and it is, perhaps, unrealistic to expect it to do so. Indeed, differentiation in the application of SPS measures is a necessary part of any risk-based food safety and agricultural health control system. At the country, industry and enterprise levels, there is a need to prioritize the hazards to be monitored and the control measures that are implemented, given limited resources. Further, priorities are inevitably set not only on the basis of scientific evidence but also political factors, for example where consumers and other interest groups are showing most concern (Henson 2001). As resources are limited and the implementation of SPS measures is frequently costly, an effective risk management system will go beyond the prioritization of potential hazards to differentiate explicitly between alternative sources of supply based on differences in conditions of production, past experience and assessments/perceptions of risk management capabilities in the supply chain. Indeed, many countries operate systems of automatic detention for products imported from countries with a history of non-compliance with food safety or agricultural health requirements.

In circumstances in which regulators and others have wide discretion and where various forms of differentiation are required for cost-effective management of food safety and agricultural health, there remains ample scope for 'mischief'. Yet separating legitimate differentiation from nonlegitimate discrimination is problematic. Even more difficult is clearly attributing standards to protectionist designs, considering that in most circumstances where protectionism is alleged, there are at least partially legitimate food safety or agricultural health issues involved. For example, in two widely referenced cases where protectionism is assumed to have been an important motivating factor, restrictions on exports of Mexican avocadoes and Argentine citrus fruits to the United States, there has been scientific justification for the application of measures to prevent the spread of plant diseases, albeit that are less trade restricting (Roberts and Orden 1997). In other cases, trading partners have differing perspectives on the current state of scientific knowledge and/or the need to make allowance for uncertainty. Perhaps the most prominent case is the dispute between the European Union and United States over restrictions on exports of beef produced with the use of hormones (Paulwelyn 1999 and Bureau et al. 1998).

Thus, there are remaining questions over the existence of systematic discrimination against imports in the application of food safety and agricultural health controls. One question here is whether foreign suppliers must comply with higher requirements than domestic suppliers. No 
systematic research has been done on this subject, although a great deal of anecdotal evidence is presented by those that purport to have been adversely affected by food safety or agricultural health requirements. Further, 241 complaints were raised by WTO Members in the SPS Committee over the period 1995 to 2002 (Roberts 2004). On the basis of general impressions, it would appear that many countries, both industrialized and developing, do have a lower tolerance for certain animal and plant health risks from imports than domestic sources. Indeed, there are various circumstances in which countries have restricted supplies from countries where a plant pest or animal disease occurs, even though the pest or disease in question is prevalent domestically. Similar observations can be made for some food safety controls. For example, the United States has long argued that a broad array of countries have a near zero tolerance for salmonella in imported poultry products, yet this pathogen is widely present in their domestic supply chains. Interestingly, countries can also apply discriminatory measures to different importing countries. For example, the Philippines complained that Australia prohibited imports of sauces containing benzoic acid, although similar products that contain this additive were permitted from New Zealand. ${ }^{8}$

Currently, there is a paucity of systemic research that compares the modes and intensity in which food safety and agricultural health regulations are enforced on domestic versus imported supplies. In discussions with high-value food exporters in developing countries one frequently hears the accusation that the controls they face are more rigorous than those imposed on domestic suppliers in certain industrialized countries. Frequently, however, this perception springs from the intensive oversight and monitoring provided by private entities, especially supermarkets and their buying agents, rather than from official systems of surveillance and product monitoring. Further, in many ways the methods of control they can face are more 'visible' in their effects, in that compliance is assessed at the border and on this basis entry can be denied. Domestic suppliers, however, are regulated through inspection of their processing facilities with a focus on system-based controls and/or market surveillance. ${ }^{9}$

Conversely, there is at least anecdotal evidence suggesting that regulatory oversight is substantially more stringent on domestic rather than imported supplies in the case of certain products and markets. For example, there is no official requirement in the United States for border testing of cereals or nuts for the presence of aflatoxin and the detention of imported products is exceedingly rare. In contrast, private sector testing for aflatoxin levels in cereals is commonplace in the domestic market, with frequent price discounts being applied by buyers. As another example, over a typical three year period the US Food and Drugs Administration's (FDA's) Center for Food Safety and Applied Nutrition will undertake inspections of all the domestic firms which produce low-acid canned foods, yet this applies to only three percent of foreign facilities which export such products to the United States market. ${ }^{10}$ Even after substantially increasing resources for the inspection of food imports (see below), the FDA still

\footnotetext{
${ }^{8}$ Likewise, the United States complained that the Spanish regulation on levels of copper and other minerals in imported squid was discriminatory since domestic and EC products were specifically exempted. Both of these disputes have now been resolved.

${ }^{9}$ Increasingly, however, the regulatory regimes governing domestic and imported suppliers are converging, in that foreign suppliers are also facing inspection of their facilities. Facilities that obtain a favorable outcome may be subject to less onerous regimes of border inspection.

${ }^{10}$ According to an FDA source, while 99 percent of domestic facilities are found to be in compliance, some thirty percent of inspected foreign facilities have significant system defects.
} 
only inspects between 1 and 2 percent of the more than six million consignments of food (and cosmetic products) imported each year. Certainly, for relatively high-risk products (for example fish and meat products), a higher proportion of domestic supplies is inspected by regulators. Further, both in the United States and European Union, systems for monitoring compliance with pesticide residue regulations pay considerably more (absolute and proportional) attention to domestic and/or regional supplies than to imports. ${ }^{11}$

There is also a paucity of systematic research comparing the intensity with which private buyers and distributors enforce their own standards among domestic suppliers versus suppliers in other countries, and especially developing countries. Anecdotally, one would assume that they would have less opportunity to observe directly the food safety and agricultural health control systems employed by developing country suppliers and place particular emphasis on end-product testing and/or requiring that suppliers obtain (third-party) certification of their quality management systems. This is certainly a clear trend, particularly amongst buyers in the United Kingdom and the Netherlands for example, yet it is doubtful that such requirements are being imposed on developing country suppliers at the same rate as their industrialized country competitors. ${ }^{12}$

While it is not possible to denote generalized trends in relation to the justification of discrimination in the application of food safety and agricultural health measures, it is apparent that at least the transparency of official regulatory measures has improved in the period since the SPS Agreement entered into force. Some 85 percent of WTO members have established an 'Enquiry Point' as a conduit through which other WTO Members can obtain further information on proposed food safety and agricultural health requirements. Between 1995 and 2002, WTO members submitted some 3,220 notifications indicating the nature and objectives of the proposed measure, which product(s) it applies to, whether or not it is based on an international standard and when the measure is to come into force. These notifications provide advanced warning of new or modified measures and an opportunity for trading partners to raise questions/objections to the proposed measures, both bilaterally and through the SPS Committee. Over time, it is evident that an increasing proportion of WTO members, including developing countries, have taken advantage of this opportunity to raise their concerns (Roberts 2004).

While the notification process has increased the transparency of many food safety and agricultural health measures, there remain considerable variations in standards between countries and widespread uncertainty over how certain countries are in fact implementing/enforcing their standards. Roberts et al. (1999) note the paucity of international standards for many agro-food products. They indicate that, over the period 1995-1999, the vast majority of food safety and agricultural health measures notified to the WTO were ones for which no international standard existed. ${ }^{13}$ With specific reference to horticultural products, Roberts and Krissoff (2003) find that

\footnotetext{
${ }^{11}$ See www.cfsan.fda.gov and europa.eu.int/comm/food/fs/inspections/fnaoi/reports/annual_eu/index_en.html. On the specific results of pesticide residue tests on products from developing countries, see Buurma et al. 2001.

${ }^{12}$ For example, as of August 2003, more than two-thirds of the area certified as being EUREPGAP-compliant was in only two countries--Holland and the United Kingdom. Among developing countries, only a small proportion of the area on which fresh produce is grown for the European market was so certified, with the bulk of this being in South Africa. Hence, recognizing these constraints, extended deadlines have been given to many developing country exporters and producers to adopt and gain certification against the EUREPGAP protocol.

${ }^{13}$ Only 20 percent of the notifications by low income countries and 22 percent of those of high income countries involved applications of international standards.
} 
over the same period, two-thirds of notifications involved measures for which there was no recognized international standard and many of these are maximum residue limites for particular commodity and pesticide combinations. Jaffee (2003) notes that, despite efforts to harmonize Maximum Residue Levels (MRLs) for pesticides in fresh fruit and vegetables imported into the European Union, there remain (de facto) wide variations in operative standards due to different country approaches to surveillance and enforcement.

Variations in standards are also common in other sectors. Henson and Mitullah (2003) contrast the varied standards that developing countries must meet in order to gain and maintain access to the United States, European Union and Japanese markets for fish products. While there are some overlapping requirements, especially the increasing emphasis on the application of Hazard Analysis and Critical Control Point (HACCP), there remain differences in both regulatory and technical requirements. Likewise, Mathews et al (2003) highlight the range of product and process standards required by countries to minimize the risk of salmonella in poultry and poultry products. Dohlman (2003) and Otsuki et al. (2001) discuss the significant differences among countries, not only in the maximum permitted level for aflatoxin in cereals and nuts, but also the sampling methods used to assess conformity. This lack of harmonization in both standards and conformity assessment procedures can result in increased production and transaction costs for developing country suppliers, necessitating duplicative testing and reducing their ability to achieve economies of scale in certain production or SPS management functions.

Two further trends are contributing to the increased complexity of the standards environment. First, a growing number and proportion of food safety and agricultural health measures are riskbased process standards, relating to production, post-harvest and other procedures and/or the manner in which compliance is assessed. This reflects both the inefficiency and inefficacy of end-product testing, particularly in view of the levels of risk deemed acceptable today and the emergence (or gain in prominence) of 'new' food borne pathogens. Roberts (2004) notes that, over the past decade, the major international standards organizations have devoted more of their attention and resources toward the development of common approaches to risk identification, assessment, and management (i.e. meta-standards) than to international standards per se.

Second, the proliferation of private standards, that encompasses both product and process specifications. Some of these are essentially food safety or food hygiene protocols, as with the British Retail Consortium (BRC) Technical Food Standard. Others combine a mixture of food safety, environmental and social dimensions, as exemplified by the most recent EUREPGAP Fruit and Vegetable Standard. Still others are primarily focused on social or environmental issues; examples include Social Accountability 8000, the Ethical Trading Initiative, and the Marine Stewardship Initiative. These examples are all private protocols that have been codified and are available to the public (or at least to would-be suppliers). They represent attempts to harmonize varying standards formerly applied by individual private companies. Yet, there still remains a plethora of private standards that are simply communicated through individual supply chains and can vary widely in their specific requirements.

Continued variations in food safety and agricultural health requirements alongside the progressive shift towards process-based measures have enhanced the importance of 'equivalence' of national standards and systems. A related issue is the mechanism through which 
this is recognized, involving bilateral or multilateral equivalence agreements. Currently, there is no systemic recording of equivalence agreements although, at least anecdotally, those that have evolved appear to be between industrialized countries. However, even these are limited and can take a great deal of time and effort to establish. ${ }^{14}$ Certain developing countries, including those which have become highly successful agricultural exporters, have highlighted an array of difficulties in gaining recognition for the equivalency of their food safety and other controls to those of their major trading partners (WTO 2001). However, perhaps, one of more successful and wide-ranging example of 'equivalence' is the recognition by the European Union that a broad range of developing and industrialized countries have established systems of hygienic control for fish and fishery products that offer a level of protection at least comparable to its own legislation (see the discussion below).

A parallel trend, reflecting the proliferation of private standards, is the heightened importance of certification. Certification is the process by which buyers assess the compliance with defined standards and is typically undertaken by a third party agency that the buyer recognizes as 'competent'. In this context, a crucial issue for developing countries is the establishment of certification capacity and parallel institutions through which certification bodies are accredited. Exporters in countries that lack an accreditation certification system may be forced to use the services of an accredited body in another country, most commonly an industrialized country, the cost of which can be considerable (El-Tawil 2002).

While the process of notification under the SPS Agreement has contributed to increased transparency of official food safety and agricultural health measures, this has been accompanied by the proliferation of private standards that fall outside of the purview of the WTO. Thus, the overall picture for food safety and agricultural health requirements in trade is becoming increasingly complex and fast moving as standards are promulgated in multiple spheres at both the national and international levels. Further, the complexity of this issue stems not only from the variability of standards on paper, it is magnified by differences in the ways, means and intensities by which the standards are monitored and enforced, which themselves are changing over time.

An illustration of this complexity is depicted in Figure $1 .{ }^{15}$ For a developing country exporter, the operative 'rules of the game' are derived by a combination of factors including the prevailing standards themselves, enforcement capacities and predilections of official agencies, nature of private standards and oversight arrangements such as certification, and the prominence of particular concerns among consumers and civil society organizations at any point in time. Clearly, there are potentially significant gains from the harmonization of standards, internationally, among countries and within the private sector. Yet, complexities will inevitably persist, especially as supply chains are increasingly driven by the exacting and more dynamic demands of consumers. The challenge for developing countries is clearly immense, although (as

\footnotetext{
${ }^{14}$ For example, the Veterinary Equivalence Agreement between the United States and European Union took a total of seven years to be established. Arguably, it has had little tangible impact on differences in food safety and animal health requirements as they influence trade in livestock products between the two partners.

15 This is drawn from Jaffee (2003).
} 
is discussed below) the pay-off for those that succeed is potentially significant. However one thing is certain, non-compliance is not an option for those that wish to continue to export! ${ }^{16}$

Figure 1. The evolving standards environment:

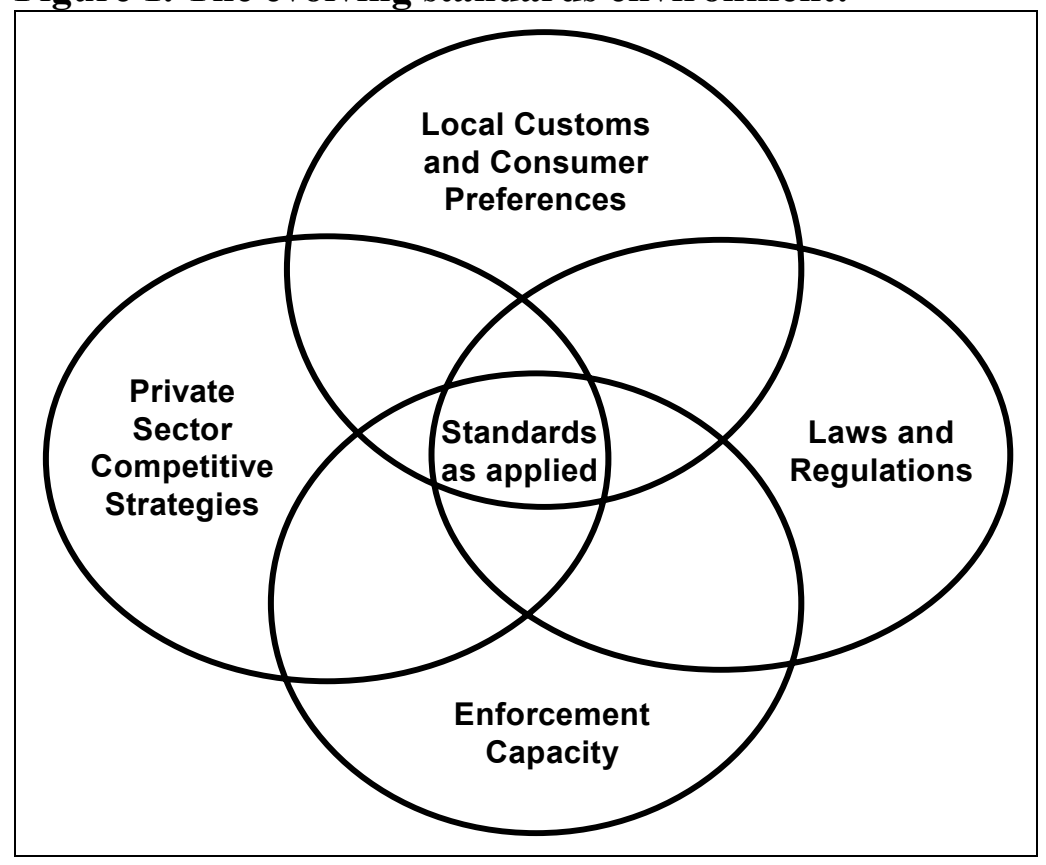

\section{WHAT CAPACITY IS NEEDED?}

Importing countries frequently require guarantees that exports are derived from areas that are free from certain pests or diseases, that minimum standards of hygiene have been applied in the manufacture, packaging and distribution of food products, or that products are free of excessive residues, for example of pesticides, veterinary medicine, environmental contaminants or naturally occurring contaminants. The exporting country must have the capacity both to comply with these requirements and to undertake the necessary actions in order to demonstrate that compliance has been achieved. ${ }^{17}$

In pursuing the development of a modern and competitive agro-food system, a country needs to have the capacities to undertake a range of SPS-related functions, some of the most important being:

\footnotetext{
${ }^{16}$ Given that these standards are most widely applied in industrialized countries, one option might appear to be a greater focus on low and middle-income markets. However, increasingly these markets are also adopting stricter food safety and agricultural health requirements. In part this reflects the demands of middle and high-income consumers, predominantly in urban markets. In turn, these demands have been reflected in the requirements of new players in food supply chains within developing countries, for example supermarkets (see Reardon and Berdegue, 2002; Weatherspoon and Reardon, 2003). Further, developing countries are being driven to enhance their domestic food safety and agricultural health controls as a means to satisfy export market requirements.

${ }^{17}$ Food safety and agricultural health management capacity is important not only to meet requirements for export markets, but also to facilitate effective controls on imported agricultural and food products and on domestic production. Indeed, in certain contexts (for example, a developing country with a significant tourism sector) these controls may be of greater importance.
} 
- Detecting the presence/demonstrating the absence of biological, chemical or physical hazards and having an information system to inform decision-making processes; employing emergency procedures in the event of emerging hazards and/or outbreaks,.

- Verification/certification of traded products with respect to established food safety risks.

- Undertaking scientific analysis of hazards in agricultural inputs and food products.

- Establishing/maintaining the identity of agricultural products through the supply chain.

- Establishing/maintaining systems for hygienic practices in agro-food product handling and transformation.

- Registering the production, distribution, and use of agricultural inputs that may pose risks to human, animal or plant health.

Administrative and technical capacities for food safety and agricultural health management are embodied in institutional structures and procedures, physical infrastructure and human capital. Frequently, it is assumed that managing food safety and agricultural health is predominantly a public sector responsibility. Indeed, there are some crucial regulatory, research and management functions that are normally carried out by governments ${ }^{18}$, and a variety of circumstances where importing countries require that certain functions be performed by a designated public sector 'competent authority'. However, the private sector also has a fundamentally important role to play. First, private should contribute to standard setting as it is typically well informed about technical options and hazard management systems. Second, it is through the specific actions of individual producers and processors that compliance with food safety and agricultural health requirements is achieved. An example is the application of HACCP within the supply chain. Third, capacity building in the private sector can complement (or substitute for) public sector capacity, as with the investment in accredited laboratory testing facilities.

The development of food safety and agricultural health management systems tends to be closely related to the availability of wider technical, administrative and scientific capacities. In turn, it generally reflects broader patterns of economic development as well as specific demands for food safety and agricultural health controls. For example, Unnevehr and Hirschhorn (2000) highlight the priorities and capacity needs for food safety management at different stages of economic development. Export-oriented agriculture does, however, provide a new set of challenges as external food safety and agricultural health requirements may differ sharply from those prevalent in the domestic market, especially in the case of low-income countries.

There is wide variation in the extent to which regulatory, technical and administrative capacities represent a significant constraint on developing country exports of agricultural and food products. ${ }^{19}$ In general, weaknesses in the management of plant and animal health issues is more likely to act as an absolute barrier to trade than lack of food safety controls. Many developing countries lack the capability to undertake effective epidemiological surveillance and to conduct

\footnotetext{
${ }^{18}$ The vast majority (88\%) of developing countries have positioned their standards institution within the public sector, frequently as a division or semi-autonomous unit of the ministry responsible for industry and commerce. In contrast, in over 50 percent of industrialized countries, the national standards institutions are in the private sector while a further 20 percent have some form of public-private institution (Henson 2004).

${ }^{19}$ An array of capacity assessment instruments are used to gauge strengths and weaknesses of food safety and agricultural health management capacity. Some instruments (i.e. that of IPPC) focus on specific dimensions of capacity, while others (i.e. that of IICA) provide a broader overview.
} 
rigorous risk assessments which are acceptable to overseas trading partners. Thus, regardless of capacity within the private sector, for example to meet the food safety and quality requirements of overseas customers, the country as a whole will be unable to gain market access.

On the other hand, core elements of effective food safety management involve awareness and understanding of good agricultural and manufacturing practices and their effective implementation. Further, the application of HACCP is fast becoming the norm within food processing and is beginning to extend down the supply chain to agricultural production. For many food safety hazards there is an array of effective technologies or approaches, some of which do not require sophisticated equipment or expertise. Still, even where the management of prevailing food safety hazards is well within the capacities of producers and processors, systems of conformity assessment require testing and certification of both food safety management systems and end-products. Here smaller and poorer countries and industries typically suffer from the absence of accredited laboratories and/or internationally recognized systems for certification (El Tawil 2002).

While many developing countries have widespread weaknesses in food safety and agricultural health management capacity, there is evidence that even low-income countries can, selectively, put in place the necessary regulatory, technical and administrative arrangements to meet demanding standards in high-income export markets. One example is the relatively large number of low and lower middle-income countries which have been recognized by the European Commission as having standards of hygiene in the capture, processing, transportation and storage of fish and fishery products that are at least equivalent to those of the European Union. These countries have been listed in Part I of the relevant EU legislation and their shipments benefit from reduced physical inspection at the border. Over the period 1997 to 2003, the number of countries achieving List I status increased from 27 to 83, with more than half of these being low or lower-middle income countries.

The SPS Agreement calls for increased external assistance to developing countries to strengthen their capacities in food safety and agricultural health management. In recent years, $\$ 65$ to $\$ 75$ million has been spent annually by bilateral and multilateral agencies on an array of programs to strengthen trade-related capacities. ${ }^{20}$ Beyond this, there are a large number of private sector initiatives, involving individual firms or wider industry groups, which contribute towards improved food safety and agricultural health management among their developing country suppliers and make provision for third-party monitoring/certifying of suppliers. Despite this, the remaining unmet needs are considerable and at the same time capacity requirements are increasing over time as food safety and agricultural health standards proliferate and lay down seemingly ever more stringent requirements.

\footnotetext{
${ }^{20}$ Based on estimates from the WTO website (www.wto.org) together with information from other agencies whose program are under-reported on that website.
} 


\section{COMPLIANCE COSTS: WHAT AND HOW SIGNIFICANT ARE THEY?}

In the context of international agro-food trade, developing countries can incur significant 'costs of compliance' whenever changes are made in international standards or those of their trading partners. Additional costs may also be incurred in response to new or more stringent food safety or other requirements of private buyers. These costs can come in various forms, including fixed investments in adjusting production/processing facilities and practices, recurrent personnel and management costs to implement food and other control systems and the public and private sector costs of conformity assessment.

Typically there are a variety of technological and administrative ways in which to achieve compliance with a certain standard. For this and other reasons the level and relative significance of compliance costs can vary enormously from industry-to-industry and between different countries. $^{21}$ Important variables include the prevailing structure and conditions of the supply chain, range and extent of administrative and scientific capacities, level of effective intraindustry and public-private cooperation, strength of existing technical service industries, and so on. In circumstances where there exists a mature and reasonably well-developed export industry, changes in food safety and agricultural health standards may necessitate only incremental changes by producers or exporters and perhaps some modest adjustment in public sector oversight arrangements. However, in circumstances where the supply chain has utilized makeshift or multi-purpose facilities and where new requirements (or new levels of enforcement) necessitate major upgrades, some firms may need to re-direct their products to less demanding markets, while others must undertake significant fixed investments.

This is illustrated in Table 1 which compares adjustment costs associated with investments in the upgrading of hygiene controls in the Bangladeshi and Nicaraguan shrimp industries. In the case of Bangladesh, major investments had to be made in the mid-1990s to upgrade fish processing facilities, product testing laboratories and other areas in response to repeated quality and safety detentions of products entering the United States and a ban in 1997 on shrimp imports into the European Union. These investments were at a level equal to 2.3 percent of the total value of the country's shrimp exports over the period 1996-98. The annual maintenance of HACCP and regulatory systems involved costs equal to 1.1 percent of exports. Between 1997 and 2002, the Nicaraguan shrimp industry needed to make adjustments to hygiene controls to ensure compliance with modified US fish safety regulations, including requirements to implement HACCP. However, since many Nicaraguan factories were relatively new and modern only modest incremental investments were needed, equivalent to 0.6 percent of the value of exports.

\footnotetext{
21 In practice, it is rather difficult to measure 'costs of compliance'. Food safety is very often achieved in combination with other business functions and is thus a joint product with those functions. Thus, there are questions over what investments and which management systems are put in place strictly to ensure compliance with particular standards and which service a multiplicity of functions? In practice, it is often difficult to make this separation. For example, cold store facilities may be needed to prevent the multiplication of bacteria in fresh produce, yet such facilities are also critical for achieving a quality characteristic or extended shelf-life.
} 
Table 1. Costs of compliance with export food safety requirements in the Bangladeshi and Nicaraguan shrimp processing sectors (US\$ million):

\begin{tabular}{|c|c|c|}
\hline Costs & $\begin{array}{c}\text { Bangladesh } \\
(\mathbf{1 9 9 6 - 9 8 )}\end{array}$ & $\begin{array}{c}\text { Nicaragua } \\
(\mathbf{1 9 9 7 - 2 0 0 2})\end{array}$ \\
\hline Industry Facility Upgrading & 17.55 & 0.33 \\
Government & 0.38 & 0.14 \\
Training Programs & 0.07 & 0.09 \\
Total & 18.01 & 0.56 \\
\hline Annual Maintenance of HACCP Program & 2.43 & 0.29 \\
\hline Shrimp Exports During Focal Periods & 775.00 & 92.60 \\
\hline Average Annual Shrimp Exports & 225.00 & 23.20 \\
\hline Upgrade/Focal Year Export & $2.3 \%$ & $0.61 \%$ \\
Maintenance/Annual Exports & $1.1 \%$ & $1.26 \%$ \\
\hline
\end{tabular}

Sources: Based on Cato and Lima dos Santos (1998) and Cato et al (2003).

Many forms of technological and organizational change involve shifts in levels and structures of operating costs. There are at least two (related) reasons why the costs associated with these changes are deemed to be 'controversial' in relation to food safety and agricultural health standards. First, there is a perception that the needed actions are not justified and represent an unnecessary cost burden on (developing country) suppliers. This lack of justification might be because these requirements lack (or are perceived to lack) scientific basis or involve burdensome arrangements when simpler and less costly procedures might provide similar outcomes. Second, suppliers may obtain little or no benefit beyond continued market access, while the opportunity cost of the required investments, for example in terms of product development or expansion of capacity, can be considerable. In many cases this latter argument is difficult to sustain and may reflect a lack of appreciation of the (often intangible or indirect) benefits that can accrue from, for example, enhancement of food safety controls. Adoption of improved control systems can result in reduced product and raw material wastage, improved product-cost accounting and enhanced staff morale. Thus, changes in product and process technologies can generate substantial increases in efficiency, reducing production costs and promoting competitiveness.

The enhancement of food safety capacity can also have more dynamic and wide-ranging impacts on private sector suppliers. For example, the implementation of a HACCP system and gaining third-party certification can send positive signals to both existing and potential customers. Firms can use these signals as a mechanism to reposition themselves in the marketplace and/or access new markets. For example, Indian fish processing plants that have invested in sophisticated systems of hygiene control are making efforts to access higher-value markets for processed and semi-processed products. Conversely, the potential burden of compliance costs can induce strategic changes as a means to avoid investments, for example through attempts to access markets with lower food safety requirements. Likewise, this can occur where problems have been experienced complying with requirements in a particular market. For example Kenyan fish exporters, that historically have been highly dependent on European markets, have made attempts to diversify their exports to countries such as Australia, Japan, and United States.

In many cases the various expenditures related to standards compliance should not be considered deadweight costs, whether in the context of industrialized or developing countries. Some of the 
needed investments may require labor, especially skilled and supervisory workers, creating additional job opportunities. Other expenditures may go towards building materials, contractors and various technical services, much of which could be sourced locally. Only in circumstances where up-grading relies primarily upon imported equipment and/or expertise, for example that might apply to certain projects funded by bilateral donors, would there be few multiplier effects from expenditures related to standards compliance.

Even where the administrative, technical and financial burden of compliance is achievable at a country or industry level, this burden may be too great a burden at the level of individual firms or producers. There is a general concern that the challenge of rising standards is marginalizing the position of smaller players, especially producers, traders and processors, as well as smaller industries as a whole, in international agro-food trade. However there is presently little empirical evidence to support this argument. In part, this is because of the difficulties in disentangling the specific and distinctive role of standards compliance in the processes of consolidation of agrofood systems.

In many cases, it is evident that compliance with food safety and agricultural health standards largely acts to exacerbate other factors that threaten the status quo in established supply chains. For example, both the Indian and Kenyan fish processing sectors were facing longer-term challenges when forced to comply with enhanced hygiene standards for exports. In the case of India, exporters were facing intense price competition from other suppliers such as Vietnam and Thailand. The Kenyan fish processing sector was characterized by chronic excess capacity because of raw material shortages. In both cases the costs of compliance with stricter food hygiene standards has induced consolidation that, most probably, would have occurred anyway, albeit over a more protracted period of time. In Nicaragua, the decline in the production share of small-scale shrimp producers had more to do with Hurricane Mitch and its aftermath than to the tightening of standards (Cato et al. 2003).

A particular concern is that smaller players can be disadvantaged where there are economies of scale or scope in the implementation of particular technologies or administrative systems. Indeed, evidence from studies of compliance with labor and environmental standards in the United States suggests that costs are proportionately higher for smaller firms. (Crain and Johnson 2001) In some cases the necessary investments have elements of lumpiness, for example laboratory equipment and cold storage facilities, which are only economically viable for largescale operations or require collective action. Likewise, hiring of certain skilled personnel is typically less problematic for medium or large firms than smaller ones. More generally, smaller firms can be 'overwhelmed' by the many changes needed to comply with new food safety requirements, for example, even though the actual cash investments that are required may not be substantial.

Producers can also be adversely affected where the transaction costs incurred by buyers when dealing with a fragmented supply base are greatly magnified by food safety requirements. Indeed, compliance with these requirements may actually be less problematic to small producers than the costs associated with the system required to record and certify that those standards have been met. For example, Kenyan vegetable exporters face considerable oversight costs in order to 
demonstrate to their major European buyers that compliance has been achieved. ${ }^{22}$ In turn, this is generating pressure (along with other commercial factors) for the rationalization of supply chains. Changes in the product composition of trade may also affect structural patterns. ${ }^{23}$ Further, in a competitive environment, exporters frequently find it difficult to control effectively the volume and continuity of small-holder supplies due to 'side-selling' on the part of farmers. Where export supply commitments are very firm and specific, exporters need more effective control and this can induce backward integration into production.

A frequent presumption when discussing the marginalization of particular suppliers is that standards compliance is a 'do or die' scenario. In reality, however, there is rarely a single market for particular products, such that suppliers do have other options. In turn, they must orient themselves to those markets (as well as market segments) where they have advantages rather than disadvantages. For example, there may be opportunities in domestic or regional markets for the same or similar products, where lower prices are offset by the avoidance of compliance challenges and costs. Directing attention towards these markets may be one way of avoiding marginalization. Thus, the development of high-value agricultural and food products sectors in the future is likely to be bimodal, with some firms up-grading and adapting and others targeting other markets and raising their capacity at a slower pace over time.

\section{WHAT IMPACT ARE STANDARDS HAVING ON EXPORTS OF HIGH-VALUE AGRO-FOOD PRODUCTS?}

Having explored the challenges posed by the proliferation and enhancement of food safety and agricultural health standards for both government and the private sector in developing countries, we now turn to the resultant impact on their exports of agricultural and food products. It is recognized that the application of food safety and agricultural health control measures by governments and related standards by the private sector can significantly affect the levels and patterns of international trade in agricultural and food products. While most of such standards are designed in pursuit of the legitimate goals of maintaining and/or enhancing human, plant and animal health, they can also serve as technical barriers to trade.

Roberts et al. (1999) provide a useful classification scheme for technical trade barriers associated with agricultural and food products, dividing potential policy instruments into three categories, namely: (i) full or partial import bans; (ii) technical specifications, including product and process standards; and (iii) information remedies, including packaging and labeling requirements and controls on voluntary (health and other) claims. Full or partial bans are the most trade-restricting measures. Total bans are typically used when there are great risks associated with certain plant and animal health problems and where no cost-effective eradication/mitigation measures are available. Partial bans may permit trade only in certain seasons or to/from certain countries or regions. These bans may apply only to imports or may also apply to inter-provincial/inter-state commerce. Both technical specifications and informational remedies will normally apply both to

\footnotetext{
${ }^{22}$ One leading Kenyan firm estimated the costs of its small farmer oversight arrangements to represent about 12 percent of its costs of raw materials. These transaction costs represent 6 percent of the FOB value of French beans, are equivalent to the exporter's profit on the product and are equivalent to about 60 percent of the grower's profit.

${ }^{23}$ Some new products may not require as much farm labor as previously traded products, or require more capital investment. In either scenario the comparative advantage of smallholders may be reduced.
} 
imports and domestic supplies. Their effects on trade will derive from the relative abilities of different suppliers to comply with these measures, the varied incidence of compliance costs and how each affects the relative competitiveness of different suppliers.

While there is general agreement that food safety and agricultural health measures do indeed strongly impact international agro-food trade, there is no consensus on the relative importance of individual measures and in relation to other trade-distorting measures, nor their aggregate net effect. Indeed, enormous difficulties are involved in empirical testing the impact of such standards on trade. Firstly, one must make assumptions about how the broad array of measures is actually enforced and how this deters or encourages potential export suppliers. Depending upon the enforcement regime, the adjustments needed by different suppliers may be very significant or quite modest. This variable cannot be aggregated and differs from country to country and among different industries. Secondly, there may be all kinds of secondary effects as a result of food safety and agricultural health requirements, for example leading to shifts in sourcing, affecting complementary and competitive goods, the spread of regulations and restrictions to other countries etc. Thirdly, often a specific measure is not a dominant or even very important determinant of observed trade flows, or lack thereof. There is a risk to ascribing shifts in trade to agro-food standards which are more fundamentally driven by other economic or technical factors. Fourthly, there are sometimes problems in defining the counterfactual situation against which the impact of such standards can be assessed. What would have happened in the absence of the measure? Would trade have been unimpeded or would distributors and consumers have sought product from other suppliers instead? In the absence of a (traderestricting) measure, might overall demand have declined for a product for which certain problems were identified? Finally, many food safety and agricultural health measures will affect domestic suppliers as well, with varied outcomes in terms of shifts in the relative competitiveness and market share of the different players.

These and other empirical problems have led researchers to devote more attention to specific cases and to attempt to highlight the role played by (changing) food safety and agricultural health requirements on bilateral or broader multi-country patterns of trade. A discussion of some such cases will be provided below. However, only one study has attempted to provide some kind of aggregated measure of the level of agricultural and food trade constrained or blocked by technical barriers. This was conducted in 1996 by the US Department of Agriculture (USDA). Drawing upon expert opinions by USDA and other regulatory personnel, it was found that 'questionable' technical barriers (that is measures judged to have no scientific basis) were inhibiting US exports of agricultural and food products to some 62 countries. More than 300 market restrictions were identified which constrained or blocked exports valued upwards of $\$ 5$ billion, equal to around seven percent of US agricultural, food and forestry trade in 1996. Twothirds of the identified measures, including nearly all full or partial import bans, addressed risks for animal or plant health (Roberts et al. 1999).

This type of broad estimate for the trade effects of food safety and agricultural health measures has not been repeated for any other country. However, partial insights into the subject have been obtained through other approaches. Most commonly, researchers have looked to the only available multi-country sources of 'data' on the subject, namely official listings of agricultural and food product detentions/ rejections by certain industrialized countries and the growing 
number of complaints which have been recorded in the SPS Committee. Both are seen as incomplete yet useful proxies for the trade inhibiting effects of food safety and agricultural health standards and each is discussed in turn below.

\subsection{Border detentions and rejections of agricultural and food products}

For a limited number of countries, information is made available (through periodic reports and web-based databases) on the incidence of detention or rejection of imported agricultural and food products on the basis of problems associated with quality, safety, labeling or other technical issues. The most widely available and cited data are for the United States and European Union. While there have been changes in the classification of data over time, researchers are able to use that data which is available to obtain a reasonable picture of the incidence of product rejections over time and by product and country of origin. However, it is only possible to track the incidence of detention/rejection event. Neither the data available for the United States or European Union specify the volume or value of rejected consignments.

There are interesting similarities and differences between the product rejection data for the European Union and United States. ${ }^{24}$ Amongst the most notable are:

- Rising incidence: With regard to both the United States and European Union there has been a very large increase in the number of detentions in the past several years. In the European Union, for example, the number of notifications/alerts increased more than sixfold between 1998 (230 cases) and $2002(1520)^{25}$ This increased incidence of rejections reflects a combination of factors including the tightening and/or harmonization of standards, application of new standards for hazards formerly unregulated and (perhaps most significantly) substantially increased capacities for inspection/enforcement. With regard to the U.S., between 2001 and 2003 there was a six-fold increase in the number of product inspections undertaken by the FDA in the United States, in part due to heightened concern about bioterrorism. ${ }^{26}$

- Product concentration: In both cases the vast majority of detentions/rejections occurred for a few product categories, namely fish/crustaceans, meat products and fruits and vegetables. For the European Union, there was also a high incidence of rejections for nuts, while for the United States there were many rejections of low-acid canned foods. In both cases, fish products experienced the highest incidence of rejections. For example, fish accounted for 35 percent of all rejections in 2002. There were comparatively very

\footnotetext{
${ }^{24}$ Data for the United States can be found at www.fda.gov/ora/oasis/ora_oasis_ref.html, and for the European Union at www.europa.eu.int/comm/food/fs/sfp/ras index_en.html.

${ }^{25}$ The FDA data exclude certain agricultural and food products for which the FDA has no jurisdiction, most notably meat and poultry. Until 2002 these data referred to border detentions regardless of whether the product was eventually permitted to enter. Since that time, however, they have recorded border rejections. The European Union has only made available disaggregated data on import alerts since 2002, although annual reports with broad summary statistics were published previously.

${ }^{26}$ Between 2002 and 2003 the number of ports where the FDA has assigned inspection staff increased from 40 to 90. Over this period, a $\$ 96$ million increase in the FDA's budget for food security work enabled it to hire 655 new field personnel. In the Bush Administration's proposed 2005 budget the FDA would receive a 9 percent increase in funding to expand its 'food defense" program. The fiscal 2005 budget calls for 97,000 import inspections, a figure which is seven times that undertaken in 2001. Similarly large increases were proposed for the Department of Agriculture's work on food safety.
} 
few rejections on quality/safety grounds for beverage crops, cereal products, feedstuffs or spices.

- Country of Origin Concentration: In both cases, a limited number of developing and industrialized countries accounted for the bulk of rejections. Among developing countries, most of the rejections were from countries which have been large/dominant suppliers of 'sensitive' products for many years (for example Brazil, Thailand, Mexico and Turkey), or newly emerging large exporters of such products (for example China, Vietnam and India). In 2002, five countries, namely China, Thailand, Turkey, Brazil and Vietnam, accounted for nearly 60 percent of EU rejections of agricultural and food product from outside of Europe. However, these are some of the countries which are simultaneously increasing their EU market share for such products, suggesting that border rejections are more of an irritant than a major problem for larger exporters.

- Minimal interception of products for low-income countries: In both cases only a very small proportion of product rejections relate to exports from low-income countries. For example, in 2002 the EU only rejected 26 consignments from low-income sub-Saharan African countries, with most countries experiencing only one or two such rejections. This reflects the fact that most of these countries are mainly exporting less 'sensitive' products in terms of food safety or agricultural health risks, or have been recognized as being fully harmonized with EU requirements for more 'sensitive' products (for example fish and fishery products) and thus subject to lower levels of border inspection.

Still, there are certain key differences in focal concerns between the United States and European Union, as illustrated by the leading reasons for product rejections. For the European Union, the largest and growing proportion of rejections is related to chemical and other contaminants in food, especially veterinary drug residues, pesticide residues and mycotoxins. Chemical contaminants accounted for nearly two-thirds of all rejections in 2002, up from 55 percent in 2000. Microbial pathogens (for example salmonella and listeria) were implicated in 30 percent of rejections in 2002, down from 41 percent two years earlier. This pattern reflects the growing harmonization of European Union standards related to an array of chemical contaminants and the increased political and technical attention to these issues within the Community. In contrast, a very large proportion of border rejections in the United States in the late 1990s was due either to the presence of filth/foreign bodies (32\%) or problems associated with the packaging or labeling of canned food products for which botulism is a risk (13\%). A comparatively much smaller proportion of rejections are due to chemical contaminants (ie.12\%)). Microbial pathogens were the reason for $17 \%$ of US rejections.

As noted earlier, neither data for the European Union nor United States systematically record the volume or value of rejected consignments. In order to obtain a rough estimate of the value of trade interrupted by technical measures, Table 2 provides estimates (based on official data and consultation with private traders) of the proportions of trade in particular products that were likely to have been detained or rejected in 2000-01. These estimates are then applied to overall trade in these various products. For simplicity, it is assumed that the proportion of trade for particular products that is subject to rejections is the same for products flowing between low, middle and high-income countries. In practice this is unlikely, although with few exceptions there is simply no data available to provide more refined estimates. Further, the point of the exercise is more to provide an 'order of magnitude' estimate of trade interrupted at national 
borders for technical reasons that will permit comparison across products and country groups by income.

This exercise suggests that the value of world agro-food trade impacted by official product rejections at the import level was $\$ 3.8$ billion in 2000-01. ${ }^{27}$ Admittedly, this is almost certainly an over-estimate since we have assumed similar levels of rejections for products entering developing countries as for industrialized countries, despite the fact that levels of standards and enforcement capacities are typically lower. Reflecting the dominant share of high-income countries in certain product groups for which detention/rejection levels are relatively high (for example meat and dairy products, other processed foods and processed fruit and vegetables) these countries are estimated to account for 53 percent of 'rejected' exports, while they account for some 63 percent of world agricultural and food product exports.

Table 2. Estimated world agricultural and food trade directly impacted by import border rejections based on technical standards, 2000-01:

\begin{tabular}{|c|c|c|c|c|c|c|}
\hline $\begin{array}{l}\text { Product } \\
\text { Group }\end{array}$ & $\begin{array}{c}\text { Estimated } \\
\text { Proportion } \\
\text { of Trade } \\
(\%)^{*}\end{array}$ & $\begin{array}{l}\text { Value of } \\
\text { High- } \\
\text { Income } \\
\text { Country } \\
\text { Trade } \\
\text { Affected }\end{array}$ & $\begin{array}{l}\text { Value of } \\
\text { Middle } \\
\text { Income } \\
\text { Country } \\
\text { Trade } \\
\text { Affected }\end{array}$ & $\begin{array}{l}\text { Value of } \\
\text { Low } \\
\text { Income } \\
\text { Country } \\
\text { Trade } \\
\text { Affected }\end{array}$ & $\begin{array}{c}\text { Value of } \\
\text { China's } \\
\text { Trade } \\
\text { Affected }\end{array}$ & $\begin{array}{c}\text { Total } \\
\text { Affected } \\
\text { Trade }\end{array}$ \\
\hline $\begin{array}{l}\text { Meat/Dairy } \\
\text { Products }\end{array}$ & 1.25 & 811 & 142 & 8 & 21 & 982 \\
\hline $\begin{array}{l}\text { Fish and } \\
\text { Fishery } \\
\text { Products }\end{array}$ & $1.00 / 2.00$ & 232 & 417 & 145 & 90 & 884 \\
\hline $\begin{array}{l}\text { Fruit and } \\
\text { Vegetables } \\
\text { and Products }\end{array}$ & $0.75 / 1.50$ & 367 & 439 & 44 & 61 & 911 \\
\hline Grains & 0.50 & 160 & 40 & 6 & 8 & 214 \\
\hline Animal Feed & 0.50 & 65 & 39 & 4 & 2 & 110 \\
\hline $\begin{array}{c}\text { Tropical } \\
\text { Beverages } \\
\text { and Products }\end{array}$ & 0.25 & 25 & 18 & 16 & 0 & 59 \\
\hline $\begin{array}{l}\text { Nuts and } \\
\text { Spices }\end{array}$ & $0.75 / 1.50$ & 16 & 33 & 30 & 1 & 80 \\
\hline $\begin{array}{l}\text { Other } \\
\text { Processed } \\
\text { Food }\end{array}$ & $1.00 / 2.00$ & 122 & 53 & 3 & 6 & 184 \\
\hline $\begin{array}{c}\text { All Other } \\
\text { Categories** }\end{array}$ & 0.25 & 199 & 112 & 19 & 6 & 307 \\
\hline Totals & & 1997 & 1332 & 275 & 195 & 3799 \\
\hline $\begin{array}{l}\text { Proportion of } \\
\text { Trade } \\
\text { Affected }\end{array}$ & & 0.70 & 1.10 & 0.93 & 1.25 & 0.84 \\
\hline \multicolumn{7}{|c|}{$\begin{array}{l}\text { *Where there are two numbers the first relates to exports of high-income countries and the second to } \\
\text { middle and low-income countries. }\end{array}$} \\
\hline
\end{tabular}

${ }^{27}$ To put this number into perspective, the estimated total costs to the United Kingdom alone from BSE-related market losses and for the various cull and disposal schemes was over $\$ 5$ billion (Mathews et al. 2003). This does not take any account of the adverse impact on the country's tourism industry. 
The estimated value of developing country agro-food border rejections is $\$ 1.8$ billion, 74 percent of which is accounted for by middle-income countries. The estimated value of low-income country agricultural and food product trade rejected at the importing country border is $\$ 275$ million, representing just less than one percent of the agricultural and food exports of these countries. The product composition of the estimated 'rejected exports' of developing country is broadly consistent with the data presented earlier on EU and US rejections. For middle-income countries, the dominant products are fish and fishery products and fruit and vegetable and products, followed by livestock products. For low-income countries, fish and fishery products are the dominant category accounting for more than half of the total estimated 'rejections'.

Until quite recently border rejections due to food safety or related technical issues can be said to have had only a modest impact on overall trade in agricultural and food products, including that of developing countries. We estimate that approximately one percent of this trade was directly affected in 2000-01. Further, only a small proportion of rejected consignments is actually destroyed at the point of import, whilst some (perhaps significant) proportion of the product is re-shipped, re-conditioned or otherwise managed for sale whether in the domestic market of the exporter or some other international market. Indeed, the proportion of agro-food trade which encounters official rejections is, for most food categories, probably substantially lower than the proportion of sales which are subjected to price discounts by private buyers because of issues related to quality defects, lack of timeliness and poor presentation. Further, the products with the highest estimated proportion of rejections are also among those for which there have been proportionally, the highest rates of growth in international agricultural trade. ${ }^{28}$

The foregoing discussion suggests that, while border rejections are undoubtedly a major irritant to exporters, in most cases they do not act as a major impediment to trade. That having been said, they are undoubtedly costly, both in terms of the value of lost product and any adverse effects on the reputation of the supplier and perhaps the country of origin as a whole. For some importing countries, the occurrence of repeated violations of food safety and other standards may result in particular suppliers or the entire country being listed for automatic detention. Subsequent shipments are detained, inspected and tested at the expense of the exporter or importer until a record of compliance has been (re)established. It can take a considerable period of time for this to be achieved and the costs associated with detentions can be considerable.(See Lamb et al 2004). Further, during this period exporters may lose customers, which are unwilling to incur the potential costs and delays associated with enhanced border formalities.

In addition, there are some indications, at least from recent patterns for certain high-income countries, that increased attention is being given to border inspections of products deemed to be 'sensitive' in terms of food safety or agricultural health risks and in relation to new regulatory concerns. If the patterns described above are indicative, we would expect to see an increasing level of border interceptions of products in the coming years. This will either increase the transaction costs incurred by certain developing country suppliers or induce them to make adjustments in their production, post-harvest and product monitoring/testing arrangements so as to minimize the occurrence of rejections.

${ }^{28}$ Hence, despite increased concern about the spread of salmonella, world trade in poultry has increased substantially over the past decade and now accounts for about 10 percent of world consumption. 
Notwithstanding the above qualifying remarks, border rejections due to food safety concerns represent only a small part of the constraint on international trade in agricultural and food products associated with food safety and agricultural health measures. In terms of the impact on aggregate trade, far more inhibiting are the broad array of measures related to animal and plant health which render large numbers of countries ineligible to supply many livestock products and food crops to other countries (see for example Sumner 2003). For example, although meat and dairy products may be subject to the highest level of rejections in global trade, these are not at all significant for low-income countries and are probably of secondary importance for most middleincome countries. While this undoubtedly reflects the existence of traditional trade protections and subsidies in industrialized countries that distort world trade, animal disease controls act to exclude many developing countries from world markets for these products altogether ${ }^{29}$. In part this reflects the prevalence of endemic infectious animal diseases in many low and middleincome countries. Indeed, the costs of establishing and maintaining disease-free areas can be considerable and is arguably beyond the means of many of the poorest countries. Further, even where there is no evidence that such diseases are present, many developing countries lack the surveillance and risk assessment capacity to demonstrate that they do in fact have areas that are disease-free and for these to be recognized as such by the OIE. ${ }^{30}$

Even where developing countries have established disease-free areas, they face the risk that trade will be disrupted should outbreaks of disease occur. A recent example is the restrictions applied to exports of poultry from Thailand and Vietnam due to an outbreak of Avian Flu. In such cases exporters may be forced to divert product to domestic markets, causing a collapse of local prices. The overall impact of animal disease issues, therefore, is to enhance the risks associated with trade in livestock products and put a great onus on public authorities to not only invest in the establishment of disease controls, but ensure their continued efficacy over time.

The pattern of low-income countries in livestock trade essentially reflects an inability to meet a broad array of food safety and agricultural health requirements, both pertaining to livestock disease and hygiene controls. Indeed, most low-income countries, for example, are restricted to trade in live animals (on the hoof) rather than livestock products, for which attention need not be given to hygienic slaughter in an abattoir, meat inspection and refrigerated transport. ${ }^{31}$ Examples include intra-regional trade in West Africa and supplies from East Africa to the countries of the Persian Gulf. However, even if animal disease and hygiene capacity could be enhanced, these countries would need to compete with well-established livestock product exporters, for example Argentina and Australia, which are more reliable producers with fewer animal health problems and more standardized production. (Upton 2001). That having been said, Perry et al. (2003) demonstrate the very considerable benefits for developing countries from access to high-value

\footnotetext{
${ }^{29}$ For example, currently the United States currently only permits imports of beef from only 33 countries and imports of chicken from only four countries.

${ }^{30}$ Currently, the OIE only recognizes 57 countries as being totally free of FMD without vaccination, of which 26 are developing countries and only three are low-income countries. For further information see www.oie.int.

${ }^{31}$ Indeed, more widespread cases of both new and well-established animal diseases have led to heightened concerns about the role of international trade in the spread of such diseases. In the case of BSE, widespread restrictions have been applied to trade in live animals, meat, animal feed and an array of by-products used in the cosmetics, pharmaceutical and other industries.
} 
markets afforded by investment in the establishment and enhancement of animal disease controls, through a case study of Food and Mouth Disease (FMD) controls in Zimbabwe.

Similar issues arise with plant pests and diseases and, indeed, arguably these currently have the greatest impact on many developing countries given the importance of trade in fresh fruit and vegetables, grains, nuts etc. For example, many Caribbean countries are restricted in the fresh fruit and vegetables they can export to the United States because of the presence of various species of fruit fly. In some cases exports are prohibited altogether, whilst in others prescribed treatments are required. These treatments can involve fumigation or use of hot water to kill any pests that may be present. Such treatments not only impose costs on the exporter, but can also reduce shelf-life and degrade product quality. Further, the costs of establishing such facilities can be considerable. A case example is Jamaica that is unable to export mango to the United States because of the presence of West Indian and Caribbean fruit fly. The US Animal and Plant Health Inspection Service (APHIS \} requires that mangoes undergo hot water treatment to kill any flies that might be present on the fruit, but no facility currently exists in Jamaica.

In some cases the impact of plant disease controls on trade in agricultural and food products can be mitigated through cooperation between governments, for example through the sharing of plant pest surveillance data or the establishment of pre-clearance programs. For example, a preclearance program for exports of fresh produce to the United States has been established in Jamaica, under the supervision of APHIS officers. This enables plant pest problems to be detected prior to export from Jamaica and facilitates import to the United States with little or no further inspection. By 2001, 64 products had been approved for pre-clearance, including fruit, vegetables, roots and tubers, herbs and spices, and ornamentals plants and flowers. Around 80 percent of all exports to the United States now go through the pre-clearance program.

\subsection{Disputes and complaints through the WTO}

Another indicator commonly used to depict the nature and breadth of the standards challenge for developing countries is the number and nature of complaints and counter-notifications made through the SPS Committee within the context of the WTO. Table 3 from Roberts (2004), provides a summary of the pattern of complaints according to regulatory goal and the country group raising the issue or being the subject of a complaint. On the face of it, these data suggest developing countries have actively used the formal review and complaint process of the SPS Committee to register their concerns with respect to a significant number of notified measures, both by developed and other developing countries. Taking a more detailed look at the individual complaints, however, the following observations can be made:

- Given the nature of the counter-notification database and the information provided in most of the actual counter-notifications, it is not possible to quantify the levels of developing country trade which has or might be affected by the contested measures.

- Complaints by developing countries are dominated by a handful of countries, in particular Argentina, Brazil, Chile and Thailand. Each of these countries has issued or supported more than a dozen complaints, with Argentina alone being involved in more than a quarter of all cases of developing country complaints. These four countries have been involved, in one way or another, in the vast majority of complaints by developing 
countries. Only a handful of other countries, including Uruguay, the Philippines, South Africa, Ecuador and India, have been involved in multiple cases. This pattern of participation reflects the prominence of certain countries in the trade of a few product categories, especially beef and horticultural products, rather than the overall structure of developing country agricultural and food trade.

- Low-income countries are weakly represented in the pool of counter-notifications, issuing or supporting complaints in only five cases. This could partly be a reflection of the structure of their exports (that is they concentrated in commodities for which food safety and agricultural health measures are of lesser importance) or their limited capacity and/or confidence to participate in the SPS Committee. Their lack of formal complaints is, however, not because of their ability to resolve effectively their concerns bilaterally. Thus, these data alone provide us with very little information regarding the extent to which food safety and agricultural health measures are inhibiting the exports of lowincome countries.

- Among the seemingly large number of developing country complaints there are a limited number of concerns which repeat themselves time and time again, yet with slight variations from context to context. In relation to animal health, the vast majority of complaints relate to what are claimed to be over-restrictive (and non-scientifically based) measures with respect to FMD and beef products or BSE and animal by-products for pet food, animal feed, cosmetics etc. In the case of plant health, the large majority of complaints relate to claims of overly-restrictive measures for plant diseases/pests for to horticultural products. Food safety-related complaints are a mixture of quite specific concerns with no large clustering around any particular theme. Surprisingly, given its huge importance for developing country trade, there are rather few complaints issued in relation to measures governing fish products.

- The reasons for developing country complaints are varied, yet the vast majority involve concerns about either the 'lack of scientific evidence' in relation to food safety, absence of risk assessments in relation to plant health, and inconsistencies between country and international standards in relation to animal health.

- Among developed countries, the European Union has been the subject of the largest number of complaints by developing countries. For example, there were more than three times as many complaints against the European Union than against the United States. Several reasons might account for this. Firstly, the process of harmonization of food safety and agricultural health measures within the European Union has often resulted in the adoption of the most stringent standards previously applied by individual Member States. Secondly, the European Union has more frequently and most visibly embraced the 'precautionary principle' when adopting certain standards, sometimes giving rise to controversies over the scientific basis for these measures. Thirdly, due to the complex administrative structure of the European Union, some countries reportedly find it difficult to resolve concerns through bilateral discussions and therefore need to more readily use the venue of the SPS Committee to take up concerns with the European Commission. 
Table 3:Counter-notifications relating to new measures in the SPS Committee, 1995-2002*:

\begin{tabular}{|c|c|c|c|c|c|}
\hline \multirow{2}{*}{$\begin{array}{c}\text { Complaints against } \\
\text { measures of }\end{array}$} & \multicolumn{5}{|c|}{ Regulatory Goal of Contested Measure } \\
\hline & $\begin{array}{c}\text { Plant } \\
\text { Health }\end{array}$ & $\begin{array}{l}\text { Animal } \\
\text { Health }\end{array}$ & $\begin{array}{c}\text { Human } \\
\text { Health }\end{array}$ & Other & Total \\
\hline \multicolumn{6}{|c|}{ Number of Complaints by Developed Countries } \\
\hline Developed Countries & 16 & 7 & 44 & 3 & 70 \\
\hline Developing Countries & 17 & 11 & 41 & 4 & 73 \\
\hline Multiple Countries & - & 2 & - & - & 2 \\
\hline Sub-total & 33 & 20 & 85 & 7 & 145 \\
\hline \multicolumn{6}{|c|}{ Number of Complaints by Developing Countries } \\
\hline Developed Countries & 12 & 12 & 34 & 2 & 60 \\
\hline Developing Countries & 8 & 17 & 7 & 2 & 34 \\
\hline Multiple Countries & - & 2 & - & - & 2 \\
\hline Sub-total & 20 & 31 & 41 & 4 & 96 \\
\hline Total & 53 & 51 & 126 & 11 & 241 \\
\hline
\end{tabular}

Source: Roberts (2004)

Hence, the growing number of recorded complaints or counter-notifications by developing countries provides only a very crude indicator of the extent to which food safety and agricultural health measures impede their trade in high value agricultural and food products. These complaints probably represent the 'tip of the iceberg' as most concerns and disputes are raised bilaterally and the majority of negotiations are handled by technical organizations rather than country trade representatives. Some of the complaints have occurred in the context of expanding trade ties in which the previous non-effect (or at least nuanced effects) grows more serious with expanded levels of trade. There is little basis for associating the growing number of complaints with deliberate protectionism; the nature of many of the concerns seems to be more related to inadequate (scientific) information rather than discrimination. Further, the apparatus of formal complaints relates only to mandatory standards set by public agencies. As noted above, a growing array of standards are being set privately, either through consensus within particular industries or by the 'gate keepers' of the dominant supply chains. While many such standards are ostensibly voluntary, they are becoming the de facto standards to gain or maintain access to particular buyers or market segments.

\section{SOME ILLUSTRATIVE CASE STUDIES}

The available data on agricultural and food product rejections and disputes related to food safety and agricultural health measures provide certain insights yet an incomplete picture of how these are affecting the exports of developing countries. As a result, there is increased attention being given to case studies with analysis provided on the short or longer-term effects of specific standards or compliance problems on the trade of both particular countries and particular products. Earlier work of this nature has emphasized the potential disruptive impact which food safety and agricultural health measures have (or could have) on agricultural and food exports 
from developing countries. (Otsuki et al. 2001; Herath 2001; Rahman 2001; Zaramba 2002; Wilson and Otsuki 2003). However, recent publications by the USDA (Buzby 2003) and the International Food Policy Research Institute (IFPRI) (Unnevehr, 2003) contain a series of case studies which point to more varied experiences. Other programs of case study analysis have been undertaken by United Nations Conference on Trade and Development (UNCTAD), United Nations Environment Program (UNEP) and the World Bank which provide a similar perspective. $^{32}$

The space available here does not permit a synthesis of this rapidly expanding literature. Rather, we draw upon some selected examples to illustrate the varied and complex ways in which SPS measures can impact on development country exports, either negatively or positively. Attention is focused on three of the most prominent concerns raised in the literature: (i) fish trade bans and their wider supply chain effects, (ii) limits on mycotoxins as trade barriers, and (iii) the strengthening of horticultural product and process standards.

\subsection{Fish bans and their wide supply-chain effects}

Over the last decade, developing country exports of fish and fishery products have increased at an average rate of six percent per annum (Delgado et al. 2003). However, one of the major challenges facing developing countries in seeking to maintain and expand their share of global markets is progressively more strict food safety requirements, particularly in major industrialized countries and regions. Previous studies suggest that exporters in a number of countries have experienced not inconsiderable problems complying with these requirements. ${ }^{33}$ Whilst the associated costs of compliance can be significant, however, the returns in terms of continued and/or expanded access to high-value markets often more than compensate.

The European Union lays down harmonized requirements governing hygiene throughout the supply chain for fish and fishery products. Processing plants are inspected and approved on an individual basis by a specified 'Competent Authority' in the country of origin, whether a European Union Member State or a Third Country, to ensure that they comply. The European Commission undertakes checks to ensure that the Competent Authority undertakes this task in a satisfactory manner. Imports from Third Countries are required to have controls that are at least equivalent to those of the European Union ${ }^{34}$. Countries for which local requirements have been recognized as equivalent are subject to reduced physical inspection at the EU border. Countries that have not yet met these requirements, but which have provided assurances that their control are at least equivalent to those of the European Union are currently permitted to export, but are subject to higher rates of border inspection. Initially the deadline for all countries to be fullyharmonized with the EU's hygiene standards was 31 December 1996. However, this has been extended on numerous occasions and the current deadline is 31 December 2005.

\footnotetext{
${ }^{32}$ For the case studies produced by UNCTAD see: r0.unctad.org/trade_env/test1/openF1.htm. For the case studies produced by UNEP see: www.unep.ch/etu/publications/Ctry_studies.htm.

${ }^{33}$ See for example Henson et al., 2000; Rahman, 2001; Musonda and Mbowe, 2001; UNEP, 2001a; 2001b and Zaramba, 2002.

34 The European Commission has presented its controls on hygiene for imports of fish and fishery products as a practical example of the application of equivalence (WTO, 2002). Thus, rather than laying down specific requirements, the Commission focuses on the conditions under which products will be equivalent to those produced in the European Union.
} 
Kenya provides an example of longer term efforts to comply with the EU's food safety requirements, overlaid with the necessity to overcome restrictions on trade relating to immediate food safety concerns. The major export of fish from Kenya is Nile perch derived from Lake Victoria. Until the mid-1980s this was a relatively minor species in the Lake Victoria fishery, but subsequently came to dominate the landed catch through the 1990s. At the end of the 1980s, this was accompanied by a shift in focus from local to export markets and by the mid-1990 Nile perch accounted for over 90 percent of Kenya's exports of fish and fishery products, with a value of around $\$ 44$ million in 1996. The majority of these exports were destined for the European Union. Through the 1980s there was significant investment in industrialized fish processing facilities and by the mid-1990s 15 facilities were in operation. At the landing beaches, however, there was little or no change in fishing methods or the development of marketing facilities.

Initially, Nile perch exports were extremely profitable. However, capacity soon exceeded the available supply of fish, a situation that has pervaded the supply chain for Nile perch ever since and sets the competitive environment in which all levels of the chain operate. Although food safety requirements in their major export markets were evolving, most notably the European Union, most processors made little or no attempt to up-grade their facilities and systems of procurement, processing and marketing. Likewise, the legislative framework of food safety controls remained largely unchanged, despite the fact that the structure and focus of the supply chain had shifted to exports. The overall picture was of a supply chain that had not been upgraded in line with the growth in exports and was unable to implement effective controls within the context of rapidly evolving standards overseas. Thus, both the public authorities and exporters were in a continuous position of problem-solving.

In recent years exporters of Nile perch in Kenya (as well as Tanzania and Uganda) have faced a catalogue of restrictions on trade with the European Union. In 1996, Salmonella was detected in a number of consignments of Nile perch from Kenya, Tanzania and Uganda at the Spanish border and Spain immediately prohibited imports. In April 1997, the European Commission introduced a requirement for Salmonella testing of all consignments of Nile perch from the region. Following an outbreak of Cholera across East Africa, this was extended to all fish and to cover Vibrio cholerae and Vibrio parahaemoliticus. These requirements were eventually lifted in June 1998. In March 1999, a suspected case of fish poisoning with pesticide was identified in Uganda. The European Union subsequently imposed a ban on exports of Nile perch in April 1999 which, in the case of Kenya, was not lifted until December 2000. In each case, the impact on the Nile perch sector was immediate. Exports declined, although over time these were partially offset by increased sales to other markets. Fish processing plants, most of which were already operating at less then 50 percent capacity, reduced their production and some closed. In turn, the landed price of Nile perch fell.

In response to the 'crisis' created by the European Union's actions, efforts were made by both the government and private sector in an attempt to up-grade food safety controls. Initially, responsibility for regulatory controls was split between the Ministry of Health and the Fisheries Department of the Ministry of Agriculture and Rural Development. This created significant coordination problems and poor delineation of responsibilities, delaying necessary reforms to 
regulatory systems. Subsequently, however, the Fisheries Department was made the sole 'Competent Authority' and legislation was quickly revised in line with the EU's requirements.

Simultaneously, fish processing plants up-graded their facilities and implemented HACCP. The total cost of these improvements is estimated to be $\$ 557,000$, with an average cost per plant of around $\$ 40,000$. Whilst this may not seem a huge investment, particularly relative to the value of exports, it is evident that the costs were prohibitive for a number of processing facilities and they closed. Thus, in view of prevailing levels of excess capacity, the European Union's requirements have induced rationalization of the processing sector. Simultaneously, fish processing companies began to cooperative with one another in order to present a united voice to the Kenyan Government and European Commission. In 2000 the Kenya Fish Processors and Exporters Association (AFIPEK) was formed. This has developed a code of Good Manufacturing Practice for the sector, which is adopted on a voluntary basis by its members.

A remaining weakness in the Nile perch supply chain is standards of hygiene at landing beaches. Over time, most attempts by the government to implement effective management of the fishery resource and marketing arrangements have failed. In many cases, only recently have most efforts been made to provide toilets, paved and fenced landing areas, potable water and covered markets. This is undoubtedly the biggest compliance issue facing the sector in the short to medium-term if access to EU markets for fish and fishery products is to be maintained.

It is evident that the efforts of the Kenyan Government and private sector eventually paid off. In December 2003, the European Commission recognized the controls in place as equivalent to those in the European Union. However, this case illustrates the very significant impact that stricter food safety requirements can have on a supply chain that is almost entirely exportoriented and largely dependent on a single market. It also demonstrates how such requirements can exacerbate existing pressures for restructuring and reform, whilst prevailing supply and capacity issues constrain the manner in which the various levels of the chain is able to respond.

The European Union's hygiene requirements for fish and fishery products, and more specifically, the imposition of restrictions on exports through the period 1997-2000, have had profound effects on the Nile perch sector in Kenya and its course of evolution. Whereas the export supply chain developed with a central focus on European Union markets, today most exporters have diversified their export base and have major markets in (amongst others) Australia, Japan and the United States. However, ironically, compliance with European Union requirements has better enabled Kenyan exporters to access and maintain these markets.

The Kenyan case illustrates the great inter-dependencies between the various levels of the supply chain, and between the public and private sectors, in meeting food safety requirements in export markets. It also demonstrates the importance of responding to emerging food safety and agricultural health standards in both a proactive and offensive manner. The periods of restrictions faced by Kenyan exporters of Nile perch very much reflect the fact that little had been done in response to the implementation of more strict food safety requirements in the country's most important export market. Rather, most of the concerted effort to comply with these requirements was stimulated by the sudden loss of market access, in very much a 'crisis management' mode of operation. 


\subsection{Limits on mycotoxins as trade barriers}

Mycotoxins are toxic by-products of mold infestations, affecting as much as a quarter of global food and feed crop output. (Dohlman 2003; Reddy et al. 2002) They commonly occur in the production of corn, wheat and peanuts, causing considerable crop losses. (Bhat and Vasanthi 1999; CAST 2003) Their incidence is heavily affected by climatic conditions and insect infestation, although proper production and post-harvest (especially storage) practices can strongly mitigate occurrence. ${ }^{35}$ Food contaminated by mycotoxins can be very harmful to consumers; consuming foods with very high levels of mycotoxins can and has been fatal, while long-term consumption of foods with lower levels has been linked to the incidence of liver cancer. Since the discovery of mycotoxins in the 1960s, regulatory limits have been established in 77 countries to protect consumers. (Egmond 1999) However, there are wide differences in national standards, linked to different susceptibilities to the problem and to distinct perceptions of acceptable health risks. For example, among the 48 countries that have established limits for aflatoxin in food, the acceptable tolerances range from zero to 50 parts per billion (ppb).

There are varied indications that mycotoxin problems have disrupted developing country trade. For example, Thailand was once among the leading world exporters of corn. However, due to persistent aflatoxin problems Thai corn regularly sold at a discount, costing the country an estimated $\$ 50$ million a year in reduced export revenue. ${ }^{36}$ Similarly, India was historically a significant supplier of peanut meal to the European Union, yet this trade declined sharply in the early 1980s due to problems meeting stricter standards for aflatoxin. Perhaps the most widely cited study on this subject is that reported by Otsuki et al. (2001). ${ }^{37}$ The focus of this work is the process of harmonization of the European Union's standards for aflatoxin and the potential impact on exports of selected products, including cereals, dried fruit and nuts, from African countries. Over the years, individual EU Member States had developed and applied their own tolerance standards for aflatoxin. In 1997, the EU proposed a set of harmonized standards and a uniform sampling procedure for testing. In response to the EU's notification to the WTO, developing countries raised a series of objections, related both to the proposed standards and associated sampling methods in conformity assessment. The proposed standards were to be far more stringent than the proposed Codex standard yet, it was suggested, without proper scientific justification. $^{38}$

\footnotetext{
${ }^{35}$ Although the growth of mycotoxin-producing molds is an endemic problem in humid areas, the management of this problem need not involve very sophisticated nor costly measures. See Boutrif (1997), Park et al. (1999) and Dimanche and Kane (2002) for examples of practical and low-cost measures.

${ }^{36}$ There, most of the problem occurred during post-harvest as the harvested maize was typically stored in moist if not wet conditions for one to two months prior to sale and processing. (Tangthirasunan n.d.)

${ }^{37} \mathrm{In}$ fact, this is probably the most widely cited paper in relation to the potential/actual impact of rising food safety standards on exports of agricultural and food products from developing countries.

${ }^{38}$ In response to the objections raised, the European Union revised some of its proposed measures. In its 1998 Directive, the EU established a limit for total aflatoxin in groundnuts subject to further processing at $15 \mathrm{ppb}$, and a limit for aflatoxin B1at 8ppb. This was consistent with the proposed Codex standard. For other nuts and dried fruit subject to further processing, more stringent limits were set at 10ppb for total aflatoxin and 5ppb for aflatoxin B1. In this case there was no equivalent Codex standard. The strictest standard was set for cereals, dried fruits and nuts intended directly for human consumption with maximum levels of $4 \mathrm{ppb}$ for total aflatoxin and $2 \mathrm{ppb}$ for aflatoxin B1. Again, there was no equivalent Codex standard.
} 
Otsuki et al. (2001) argued that these standards are unnecessarily stringent given the estimated level of risk reduction that would be achieved. However, their work is widely cited for another reason, namely its econometric estimation of the potential 'loss' of African trade which might be attributable to the change in the European Union's standard. Using a gravity model, which incorporates a number of variables assumed to impact bilateral trade flows, it compares existing levels of African exports to the European Union with: (i) what they would likely be following the implementation of the new standards; and (ii) what they might have been had the EU adopted the Codex standard of $15 \mathrm{ppb}$ across all of the product categories. It indicates that African exports to the European Union of cereals, nuts and dried fruit totalled $\$ 770$ million, but that this would decline to $\$ 372$ million following the adoption of the standard, a reduction of around $\$ 400$ million. Conversely, had the EU adopted the Codex standard, it is estimated that African exports of these products would have increased to $\$ 1.039$ billion. Hence, the decision by the European Union to adopt the more stringent standards was estimated to have 'cost' Africa some \$667 billion.

The conclusions of this work were headline grabbing yet widely misinterpreted. Many subsequent commentators have mistakenly referred to the estimates as if they were 'actual' losses of trade rather than the results of an econometric simulation exercise. There are a number of shortcomings with this method that need to be taken into account when interpreting these results. ${ }^{39}$ However, the major focus here relates to the value of exports, both before and after the adoption of the European Union's standard, and the lessons which stakeholders are taking from this example.

One particular problem relates to the trade data used in the study to establish the baseline. Otsuki et al. (2001) presented data suggesting that African exports to the European Union (in 1998) were \$472 million for dried fruit and nuts and \$298 million for cereals, with the bulk of this trade seemingly occurring with France. These figures seem implausible, especially for cereals given the lack of African competitiveness in this sector vis-à-vis Europe. Indeed, statistics from UN COMTRADE show a much lower level of European imports from Africa in 1998, amounting to \$104 million of dried fruit, \$45 million of groundnuts, \$27 million of other edible nuts and less than $\$ 14$ million of cereals and cereal products. ${ }^{40}$ This suggests that the baseline against which the impact of the standards should have been assessed is $\$ 190$ million (CIF value) rather than $\$ 770$ million.

Turning to the evidence on impact, the bulk of this should relate to Africa's trade in dried fruit. Most of the region's dried fruit trade is accounted for by two North African countries-- Tunisia and Algeria--whose exceptionally dry climate contributes to a very low incidence of aflatoxin. The only other African country with any history and recent strength in exports of dried fruit is South Africa. The new EU standards came into full force in April 2002. Both in the year proceeding and the year following that date there were zero cases of dried fruit consignments from Africa being detained on entry to the European Union. In fact, while total imports of dried fruit declined somewhat in 2002, imports from Africa increased, expanding Africa's share of the

\footnotetext{
39 See, for example the discussions about gravity models and other approaches to estimating the trade impacts of standards in Beghin and Bureau (2001), OECD (2003) and Wilson (2003).

${ }^{40}$ In that year, exports from the African continent of cereals totaled \$105 million, with Egypt accounting for $\$ 70$ million. The vast majority of this trade was conducted with countries of the Near East and Middle East.
} 
European Union market from 9.8 percent in 2001 to 10.3 percent in 2002. Competing countries with more humid conditions (especially Turkey) have incurred higher levels of product rejections over the past year. Ironically it could be argued that, at least for dried fruit, the more stringent European Union standards and the greater enforcement of those standards at border points has worked to the competitive advantage of Africa's leading suppliers.

But what about the impact on Africa's trade in groundnuts? Africa's groundnut exports are dominated by South Africa, although several other countries, including Egypt, Sudan, Gambia, and Senegal, have maintained small exports in confectionery nuts. A variety of supply-side constraints have inhibited the competitiveness of many African countries in the international market for this product. ${ }^{41}$ In 2002, South Africa had 12 consignments of groundnuts rejected by EU Member States because of aflatoxin. However, of these twelve only three would have met the Codex standard; the remaining nine consignments would have also been rejected on the basis of both the Codex standard and the standards that had previously been applied by the individual Member States. Indeed, most of the rejected consignments had total aflatoxin levels of between $18 \mathrm{ppb}$ and 30ppb. These consignments were returned to South Africa (presumably for sale elsewhere) rather than destroyed. Probably a few hundred thousands of dollars of business was affected, although the probable re-routing and further sale of these nuts would have substantially mitigated these losses. Hence, we would suggest that the near-term 'loss' of African trade due to the more stringent European Union standards has actually been in the hundreds of thousands rather than the hundreds of millions of dollars. ${ }^{42}$

While the case for significant African trade losses is weak, compliance with the European aflatoxin standards continues to be a challenge for selected developing countries. Between 2000 and 2002 there was a three-fold increase (from 92 to 251) in the number of border rejections of nuts, nut products and other snacks. In 2002, some 235 consignments of nuts and dried fruit were rejected specifically on the grounds of excessive levels of aflatoxin. The vast majority of these rejections were of products from three countries, namely Turkey ( 77 cases involving hazelnuts and dried fruit), Brazil (51 cases of mainly Brazil nuts) and Iran (50 cases of mainly pistachios). Other countries with more than just a few rejections were China (18), South Africa (12), United States (7) and Argentina (5).

Although the data are incomplete, for many months the European Union notifications and alerts database reports the actual test results for levels of aflatoxin. In the vast majority of cases where consignments are rejected, the measured levels of aflatoxin are substantially higher (and sometimes many times over) than the Codex standard and also significantly above the domestic standards of the exporting countries. For example, of the 15 nut and dried fruit consignments rejected in January 2002 only three were above the EU but below the Codex standard. In October 2002, one country source of nuts had 38 individual consignments rejected, 15 of which

\footnotetext{
${ }^{41}$ In the 1960s and 1970s, Africa was a major world supplier of groundnuts, with large exporters in Nigeria, Senegal, Malawi and other countries. For a variety of reasons, not related to aflatoxin, these exports lost their international competitiveness and most production went to serve domestic markets or for use in oil-crushing. Over the years, research activity and the commercial trade moved away from confectionery-type varieties preferred in world markets and recent attempts to revive confectionery nut exports have encountered major problems due to inadequate seed, basic quality control and price incentives for farmers.

${ }^{42}$ We have found no evidence that Africa's limited exports to the European Union of either cereals or tree nuts has been adversely affected since the adoption of the new standards.
} 
involved aflatoxin levels of $100 \mathrm{ppb}$ or above. This suggests that suppliers, especially those producing in humid conditions, are facing considerable problems controlling against aflatoxin contamination such that they frequently achieve levels that are way above any of the standards laid down globally.

It is still unclear, however, the degree to which the European Union's standards on aflatoxin have impacted on developing country trade. For example, Iran has been experiencing problems with aflatoxin for a number of years. Its exports of edible nuts have declined from some $\$ 452$ million in 1996 to less than $\$ 210$ million in 2002. Further analysis is needed to determine the degree to which this decline can be attributed to problems with aflatoxin contamination and, of this, how much is due to regulatory measures as opposed to a more general loss of buyer confidence in the quality and safety of pistachios from Iran. Conversely, the pertinent export industries in Turkey have apparently been little affected by the increased stringency of the European Union's standards and any increases in product rejections. In 2002, the volume of product rejected by the European Union constituted less than 1 percent of Turkish exports of nuts and dried fruit to that market. Any rejected product is either re-exported to countries with less strict standards (or enforcement), or sold domestically.

\subsection{Proliferation of horticultural product standards}

Over the past 20 to 30 years, developing countries have experienced comparatively very rapid growth in their exports of fresh fruit and vegetables (hereafter referred to as fresh produce). This trade has spread from an initial base of traditional tropical fruits (mainly bananas and pineapples) to include a broad array of fruits and vegetables. It has been stimulated by growing consumer interest in health and demand for fresh produce variety, freshness and year-round availability, and in-turn facilitated by advances in production, post-harvest and cold chain logistical technologies and by increased levels of international investment. On every continent there have been notable 'success stories' in this field alongside a range of other countries which have struggled to maintain or improve their positions in international markets. This reflects the fact that this is a highly competitive and rapidly-changing industry with multiple factors impacting on competitiveness.

The regulatory and private governance systems for international fresh produce markets are becoming increasingly complex. This changing regulatory environment appears to be raising the bar for new entrants while throwing new challenges in the path of existing developing country suppliers. Many analysts and practitioners are expressing concern about the (in)ability of small and/or low-income countries to meet rising public and private standards and thus their ability to remain competitive in international fresh produce markets. (Dolan and Humphrey 2000; Chan and King 2000; Buurma et al. 2001). Certain high-profile food scares and highly publicized instances of violative levels of pesticide residues have created an impression of extreme vulnerability on the part of developing country suppliers. Yet, experiences are mixed and more often then not those countries/industries which have run into standards-related barriers have also been struggling with other supply chain problems which have inhibited their profitability and competitiveness. Here, we briefly contrast the experiences of three low income countries. 


\section{Guatemalan raspberries: a cautionary tale?}

In the late 1980s, several firms began exporting raspberries from Guatemala to the United States in certain months of the year when domestic supplies were limited (Calvin 2003 and Calvin et al. 2003). By 1996, these exports had reached $\$ 3$ million, with some 85 growers participating. In that year, however, the US Centers for Disease Control and Prevention (CDC) and Health Canada received reports of some 1,465 cases of food-borne illness associated with the parasite Cyclospora. After some time, raspberries from Guatemala were identified as the most likely source of the contamination.

While the US FDA sent a team to Guatemala to investigate, there was much scientific uncertainly and great difficulty identifying the likely source of the contamination. The association of Guatemalan growers (GBC) remained unconvinced that its raspberries were the source of the problem. It attempted to put in place a limited program to screen out potentially high-risk farms, yet this program had no effective enforcement mechanism. After another large outbreak of Cycospora-related illnesses in the spring of 1997, the GBC voluntarily agreed to stop exports of raspberries to the United States. Despite the fact that the Guatemalan government created a food safety commission with certain enforcement powers in late 1997, the FDA was unconvinced and essentially imposed an import ban on Guatemalan raspberries.

Over the subsequent two years many organizations in the United States and Canada worked with the Guatemalans to solve the problem. A 'Model Plan of Excellence' (MPE), requiring the application of certain food safety practices by growers, involving mandatory inspection by government and including a system for product traceability back to the individual grower was put in place in 1999. On the basis of this, the United States again permitted imports of Guatemalan raspberries. In 2000, however, there were two further Cyclospora outbreaks which were traced back to a single Guatemalan farm. This was subsequently removed from the MPE program. There have been no such outbreaks since.

While the MPE was technically successful, it came too late to save the industry. Facing consumer concerns, several supermarkets in the United States sought alternative sources of raspberries. Recognizing the enormous challenge in rehabilitating the reputation of Guatemalan raspberries in the eyes of both consumers and distributors, several of the leading firms in the industry (including both Guatemalan and international firms) shifted their operations to Mexico, from where they began to export larger quantities. By 2001, there were only four growers of raspberries remaining in Guatemala with exports of less than $\$ 200,000$. In contrast, Mexico's exports of raspberries have grown from $\$ 2.9$ million in 1998 to $\$ 8.9$ million in 2002, and now account for the majority of an expanding import trade into the United States.

Although the Guatemalan raspberry industry never recovered, other elements of the fresh produce industry did build upon the institutional capacity-building which took place under the MPE. For example, the inspection agency, the Integrated Program for Agricultural and Environmental Protection (PIPAA), has been working closely with local blackberry growers, a leading local supermarket chain and others to enhance food safety management systems. The PIPAA is also collaborating with APHIS and the FDA in the United States to facilitate a program for Guatemalan exports of mangoes and papayas. 
Calvin et al (2003) draw several lessons from the experiences of Guatemala. Firstly, that delays in addressing food safety and agricultural health problems may adversely affect an industry's exports and reputation. Secondly, that an effective traceability system allows trade restrictions to be overcome through particular growers and/or exporters, rather than needing to enhance standards in an entire industry. Finally, strong grower organizations can improve an industry's ability to respond to food safety challenges. Further, there is a wider lesson from Guatemala's experience. Small countries and niche products are probably far more vulnerable to loss of markets and collapse of reputation in the face of food safety problems then would be the case with larger countries and more mainstream or generic products. One suspects that both international buyers and consumers would be more tolerant and patient with core and longstanding suppliers which have established a national 'brand' in which they have confidence.

\section{Kenyan fresh produce exports: some success ${ }^{43}$}

Kenya's fresh produce trade dates to the mid-to-late 1950s, when small quantities of temperate vegetables and tropical fruits were supplied in the European winter 'off-season' to up-market department stores in London. This off-season trade continued and was later joined by yearround-supplies of high-quality green beans and a broad array of vegetables that comprised part of the traditional diets of the UK immigrant population from South Asia. Most of the product was air-freighted ('loose') in two-kilogram boxes for sale through wholesale markets or to distributor/caterers.

For many years, the industry functioned with very simple supply chains, involving little investment in infrastructure, product development or management systems. Around a dozen medium-sized firms alongside large numbers of small, part-time operators handled the exports, frequently trading with relatives or similarly small-scale companies in Europe. Fresh produce was purchased from large numbers of small and larger growers. Produce was generally collected in cardboard boxes from farms or along roadsides, from where it was brought to a central (typically dingy) warehouse, sifted through and re-graded if necessary, cooled a little and trucked to the airport for shipment in the evening. Some limited inspection of produce was undertaken by Ministry of Agriculture officials at the airport. With relatively few exceptions this was more or less the 'model' of the industry from the 1960s through to the mid-to-late 1980s. The industry remained competitive in some markets and for some products, but not for others. While experiencing some growth in the 1970s, the Kenyan fresh produce export trade more or less stagnated in the 1980 s.

Since the early 1990s, however, the industry has been reshaped and transformed, both in response to and in anticipation of commercial, regulatory and private governance changes within its core external markets. Commercial pressures came in the form of saturated markets for certain products and increased competition from various suppliers which had improved their supply capabilities and had less expensive sea or air-freight costs than did Kenya. Commercial changes within Europe also required a shift in the Kenyan approach. In many countries, large supermarket chains were in ascendancy while wholesale markets were declining in importance or taking on more specialized roles. Consolidation was also occurring among importers, packers and distributors. Hence, the growing segments of the fresh produce market were being managed by fewer players. On the regulatory front, there was a steady wave of activity geared toward

\footnotetext{
${ }^{43}$ This discussion draws from Jaffee (2003).
} 
strengthening and harmonizing European Union and Member State regulations and monitoring systems for food safety, quality conformity and plant health. Interspersed in this wave of regulatory activity were progressively refined private sector standards or 'codes of practice' governing food safety, plant health and other issues.

Several of the leading Kenyan exporters caught an early glimpse of this 'new world' fresh produce environment and began to re-orient their operations. With the encouragement of several UK supermarkets they began to experiment with new crops. New consumer packaging was introduced and different combinations of vegetables were included. An increasing proportion of product was directed to selected supermarket chains. The latter began to send 'audit' teams to Kenya to check hygiene and other conditions on farms and in pack-houses. Improvements and investments were recommended, and in some cases required. With renewed confidence in the future of the industry, several exporters made considerable investments in new or up-graded pack-houses and related food safety management systems for the packing of ready-to-eat, semiprepared products. Kenya thus moved beyond being a commodity supplier, with mixed salads, stir-fry mixes, vegetable kebabs and other value-added products now accounting for more than $40 \%$ of what has been a burgeoning trade over the past decade. Between 1991 and 2003, Kenya's fresh vegetable exports increased from \$23 million to \$140 million. ${ }^{44} 45$

Rising private sector and public standards have posed challenges to the Kenyan fresh produce industry, yet at the same time they have also thrown a 'life line' to the industry. Due to its location and relatively high air-freight costs, the Kenyan fresh produce sector cannot compete with many other players on a unit-cost basis. Margins have been squeezed in the market for mainstream and 'commodity' vegetables. With rising labor costs in Europe, the Kenyan industry has positioned itself as a slicer, dicer and salad-maker, all of which are labor-intensive functions. Thus far, this market segment has grown fastest in the UK, although there is increased buyer interest and consumer demand on the European continent as well. This suggests that wellorganized industries in low-income countries can indeed use stricter standards as a catalyst for change, and profit in the process.

\section{Peruvian asparagus exports: another success story? ${ }^{46}$}

The Peruvian asparagus industry is a successful example of where industry leaders and government specialists realized that it was in the best interest of the industry, as well as the country as a whole, to adopt national standards in line with international norms, and have greatly benefited as a result. Over the past decade, Peru has quickly risen to become one of the world's largest exporters of asparagus. In 2002, earnings from asparagus reached US \$187 million, representing nearly 25 percent of Peru's total agricultural exports. Peru is able to produce quality asparagus year-round, yet due to high transportation costs its exporters are unable to match prices with inexpensive asparagus from some other countries. Nonetheless, they have

\footnotetext{
${ }^{44}$ Systems for crop procurement have also been transformed with many of the leading companies investing in their own farms and/or inducing major changes in the production practices of out-growers. There has been an array of joint public/private sector initiatives to train growers in all aspects of 'good agricultural practice'.

${ }^{45}$ Not all of the industry has transformed itself. There remain around 25 smaller exporters who lack the financial resources to invest in modern pack-houses and continue to supply 'loose' produce to commission agents and others in European wholesale markets and the Middle East.

${ }^{46}$ This summary was prepared by Tim O’Brien, an agricultural health and food safety specialist at IICA, which is preparing a longer analysis of Peru's experience.
} 
continued to increase exports and gain market share by applying norms to generate consistently higher quality and internationally-certified products, leading to satisfied clients and consumers. By producing products that meet international standards, Peruvian asparagus exporters have increased production and worker efficiency and generated client loyalty, while drastically reducing the industry's risk of trade disruptions due to quality, food safety or plant disease issues.

Peru has been able to gain access to industrialized country markets for its asparagus because the industry and government have worked together to market and maintain quality national products through the adoption of national standards in accordance with international norms. In 1997, Spanish sanitary authorities claimed that two cases of botulism were caused by consumption of canned Peruvian asparagus, Peru's largest market for this product. Despite Peruvian government and private sector assurances to the contrary, press coverage of the botulism scare left an unfavorable impression among consumers in European markets, causing sales to slump. This incident helped motivate the industry and government to cooperate and take action, and reinforced the fact that one careless exporter could indeed disrupt markets, such that everyone involved the asparagus export chain needed to work together to prevent future problems.

Beginning in 1998, government officials with the Peruvian Commission for Export Promotion (PROMPEX) convinced the asparagus industry to first implement the Codex code of practice on food hygiene, not because it was the easiest but because it was the most necessary. PROMPEX specialists worked closely with industry leaders and production managers to assure the proper implementation of good hygiene standards. As a result of better hygiene practices, the industry saw improved production methods, worker efficiency and product quality. This first successful experience with an industry standard, together with commitments of government support and the increasing demands from clients for certified products, gave industry leaders the confidence to work with the Peruvian government and PROMPEX to develop and implement national standards.

Thus, when the national fresh asparagus norms were published in early 2001, because the industry was already familiar with the concept of national standards, producers quickly complied with little argument. These national norms established a quality and performance baseline for the industry that allowed many to generate the skills and experience needed to voluntarily certify under other more stringent international standards. They included HACCP, traceability systems and Good Agricultural Practice (GAP) certification. Many large exporters have reached the level where they are now able to be certified under the even more strict EUREPGAP protocol.

The increasing demand for quality Peruvian asparagus has led to investments to expand cultivation and improve infrastructure, thus increasing local incomes and decreasing unemployment in some of Peru's poorest regions. Asparagus production has created more local employment because it is a more labor-intensive vegetable than other traditional crops, and because processing facilities must be near the production fields. More employment has also been created in new secondary industries producing frozen and canned asparagus that have developed to make use of the large amount of second grade produce that does not meet the national standard for fresh export 
Looking ahead, as international regulations for food safety are becoming more stringent, the Peruvian asparagus industry has been quicker to adapt to new requirements, such as EUREPGAP for the European Union and anti-bioterrorism measures for the United States, than other industries. This reflects its prior experience of standardization and the availability of a better trained work force. This is reinforced by the combination of government and private sector leadership and cooperation, and the development and application of national and international standards.

\section{CONCLUSIONS}

This paper has provided a brief overview of the potential ways in which food safety and agricultural health standards are affecting developing country agro-food exports. Mirroring the decline in traditional barriers to trade, attention has focused on the potential role of standards as technical barriers to trade. Indeed, there are now a number of documented cases where developing countries have faced restrictions because of their inability to meet food safety and/or agricultural health requirements. In some of these, well-established sectors that are highly export-dependent have been compromised by the implementation of new and stricter standards, with negative repercussions for the livelihoods of those involved. At the same time, other countries have managed to gain access to high-value markets in industrialized countries despite the existence of exacting standards. Clearly, the situation is not as 'black and white' as some commentators suggest. What cannot be disputed, however, is that standards have become an increasingly important influence on the international competitiveness of developing countries, especially in the context of high-value agricultural and food products.

The evidence presented in this paper, although admittedly incomplete, suggests that the picture for developing countries as a whole is not overly problematic and certainly is less pessimistic than the 'standards-as-barriers' perspective that is widely presented. Indeed, rising standards serve to accentuate underlying supply chain strengths and weaknesses and thus affect the competitive positions of countries and distinct market participants. This emphasizes the importance of considering the effects of food safety and agricultural health measures in the context of wider capacity constraints and underlying supply chain trends and issues. The key question for developing countries is how to exploit their strengths and overcome their weaknesses such that they are gainers rather than losers.

At the same time, however, by raising the bar for new entrants and by placing a premium on effective safety management and logistical coordination, rising official and private standards can weaken the competitive positions of small and poorer countries and diminish the ability of small and medium-sized enterprises and small-holder farmers to remain active and profitable in export supply chains. However, there is no prospect for slowing down the pace at which food safety and agricultural health standards are changing or for applying 'special and differential treatment' such that poorer countries are permitted to meet lower requirements. Much of the impetus for these trends is coming from consumer and commercial interests, magnified by advances in technology and now by added security concerns. At the margins there remain opportunities to challenge specific requirements on a piecemeal basis on scientific or other grounds. However, the core challenge relates to the development and improvement of food safety and agricultural 
health management systems. In turn, this requires attention simultaneously to legal systems, human capital, physical infrastructure, etc.

In order to understand the ways in which food safety and agricultural health standards affect developing countries, it is necessary to appreciate the management capacity required, not only to comply with distinct requirements in alternative markets, but also to demonstrate that compliance has been achieved. Although many countries have undoubtedly struggled to meet ever more strict standards, even some very poor countries have managed to implement the necessary capacity, most commonly where the private sector is well-organized and the public sector is well-focused and supports the efforts of exporters. Looking across these countries, it is clear that there is no single 'one-size-fits-all' model to be recommended to countries striving to meet the challenges posed by standards in international markets for high-value agricultural and food products. However, it is evident that institutional frameworks are required in order to overcome the problems associated with being 'poor' and/or 'small'. These can include, for example, out-grower programs for small-holder farmers, systems of training and oversight for small and medium-sized enterprises through associations and groups, or twinning and regional networking for small countries. There is undoubtedly a need to improve and refine such efforts and approaches, but they do present useful guidance on some effective ways in which to proceed.

One of the overarching messages in this paper is the need for developing countries (as well as their exporters) to be proactive when facing new food safety and agricultural health standards. While the challenges may be immense and there are undoubtedly numerous other ways in which scarce resources can be spent, it is important not to be pushed into action by a major crisis. By thinking strategically, the enhancement of capacity can be programmed into wider and longerterm efforts to enhance domestic food safety and agricultural health management systems and export competitiveness. The alternative is that potentially large-scale investments are required over a protracted time period in order to 'put out fires'. In all of this, there is a need for the public and private sector to work together in order to identify the most efficient and effective ways in which capacity can be developed. Food safety and agricultural health controls must be seen as a collaborative effort. The efficacy of a system is only as strong as its 'weakest link'. 


\section{REFERENCES}

Bhat, Ramesh and S. Vasanthi (1999) Mycotoxin Contamination of Foods and Feeds. Third Joint FAO/WHO/UNEP International Conference on Mycotoxins. Tunis, March 3-6, 1999.

Boutrif, E. (1997) Aflatoxin Prevention Programmes. FAO. Rome.

Bureau, J.C. (2004) Raising the Bar on Products and Process Standards : Economic Principles. Prepared for World Bank training seminar on Standards and Trade, January 27-28, 2004, Washington, D.C.

Bureau, J., Marette, S. And Schiavina, A. (1998). Non-Tariff Trade Barriers and Consumers' Information: The Case of the Eu-US Trade Dispute over Beef. European Review of Agricultural Economics, 25, 437-462.

Bureau, J., Gozlan, E. and Marette, S. (1999). Food safety and Quality Issues: Trade Considerations. Organization for Economic Cooperation and Development, Paris.

Bureau, J. and J. Beghin (2001) "Quantitative Policy Analysis of Sanitary, Phytosanitary and Technical Barriers to Trade," Economie Internationale (87): 107-130.

Buurma, J, M and others (2001) "Developing Countries and Products Affected by Setting New Maximum Residue Limits of Pesticides in the EU. Agricultural Economics Research Institute, The Hague.

Buzby, J. (editor) (2003) International Trade and Food Safety: Economic Theory and Case Studies. United States Department of Agriculture. Agricultural Economic Report No. 828. Washington, D.C.

Calvin, L. (2003) Produce, Food Safety, and International Trade: Respose to U.S. Foodborne Illness Outbreaks Associated with Imported Produce, in Buzby (editor).

Calvin, L., L. Flores, and W. Foster (2003) Case Study: Guatemalan Raspberries and Cyclospora, in Food Safety in Food Security and Food Trade, edited by L. Unnevehr. International Food Policy Research Institute, Washington, D.C.

Cato, J. and S. Subasinge (2003) Case Study: The Shrimp Export Industry in Bangladesh, in Food Safety in Food Security and Food Trade, edited by L. Unnevehr. International Food Policy Research Institute, Washington, D.C.

Cato, J. and C. Lima dos Santos (2000) Costs to Upgrade the Bangladesh Frozen Shrimp Processing Sector to Adequate Technical and Safety Standards and to Maintain a HACCP Program, in HACCP: New Studies of Costs and Benefits, edited by L. Unnevehr. St. Paul, Minn.: Eagen Press. 
Cato, J., S. Otwell and A. Coze (2003) Nicaragua's Shrimp Subsector: Developing a Production Capacity and Export Market During Rapidly Changing Worldwide Safety and Quality Regulations. Case study prepared as part of World Bank program on The Challenges and Opportunities Associated with International Agro-Food Standards. Washington, D.C.

Chan, M. and B. King (2000) Review of the Implications of Changes in EU Pesticides Legislation on the Production and Export of Fruits and Vegetables from Developing Country Suppliers. Natural Resources and Ethical Trade Programme. London.

Crain, W. and J. Johnson (2001) Compliance Costs of Federal Workplace Regulations: Survey Results from U.S. Manufacturers. Regulatory Studies Program. George Mason University, Arlington, Va..

Delgado, C.L., Wada, N., Rosegrant, M.W., Meijer, S. And Ahmed, M. (2003). Fish to 2020: Supply and Demand in Changing Global Markets. International Food Policy Research Institute, Washington DC.

Dimanche, P. and A. Kane (2002) Senegal's Confectionery Peanut Supply Chain: The Challenge of Controlling Aflatoxin Levels, in Food Safety Management in Developing Countries. Proceedings of the International Workshop, CIRAD-FAO, December 11-13, 2000.

Dohlman, E. (2003) Mycotoxin Hazards and Regulations: Impacts on Food and Animal Feed Crop Trade, in Buzby (editor).

Dolan, C. and J. Humphrey (2000) "Governance and Trade in Fresh Vegetables: The Impact of UK Supermarkets on the African Horticulture Industry”. Journal of Development Studies 37 (2).

Egmond, Hans (1999) Worldwide Regulations for Mycotoxins. Third Joint FAO/WHO/UNEP International Conference on Mycotoxins. Tunis, Tunisia, March 3-6, 1999.

El-Tawil, A. (2002). An in-depth study of the problems by the standardizers and other stakeholders from developing countries - ISO/WTO regional workshops: Part 1. International Organization for Standardization, Geneva.

Henson, S.J. (2001). Appropriate Level of Protection: A European Perspective. In: Anderson, K., McRae, C. and Wilson, D. (eds.). The Economics of Quarantine and the SPS Agreement. Centre for International Trade Studies, University of Adelaide.

(2004) National Laws, Regulations, and Institutional Capabilities for Standards Development. Prepared for World Bank training seminar on Standards and Trade, January 27-28, 2004. Washington, D.C.

Henson, S. and W. Mitullah (2004) Kenyan Exports of Nile Perch: Impact of Food Safety Standards on an Export-Oriented Supply Chain. Case study for World Bank program on the Challenges and Opportunities Associated with International Agro-Food Standards, Washington, D.C. 
Jaffee, S. (2003) From Challenge to Opportunity: Transforming Kenya's Fresh Vegetable Trade in the Context of Emerging Food Safety and Other Standards in Europe. World Bank, Agriculture and Rural Development Discussion Paper No. 2. Washington, D.C.

Lee, Dae-Seob, P. Lynn Kennedy, and Stanley Fletcher (2003) Examining the Latin American Peanut Industry: A Multi-Country Econometric Trade Model. Paper prepared for the International Conference of Agricultural Policy Reform and the WTO. Capri, Italy. June 23-26, 2003.

Mathews, K, J. Bernstein, and J. Buzby (2003) International Trade of Meat/Poultry Products and Food Safety Issues, in Buzby (editor).

OECD (2003) Trade Effects of the SPS Agreement. Joint Working Party on Agriculture and Trade, Paris.

Otsuki, T., J. Wilson, and M. Sewadeh (2001) "Saving Two in a Billion: Quantifying the Trade Effect of European Food Safety Standards on African Exports," Food Policy, 26, 5 (October): 495-514.

Park, D., H. Njapau, and E. Boutrif (1999) "Minimizing Risks Posed by Mycotoxins Utilizing the HACCP Concept. Third Joint FAO/WHO/NEP International Conference on Mycotoxins, Tunis.

Pauwelyn, J. (1999). The WTO Agreement on Sanitary and Phytosanitary (SPS) Measures as Applied in the First Three SPS Disputes. Journal of International Economic Law, 2 94), 641649.

Perry, B.D., Randolph, T.F., Ashley, S., Chimedza, R., Forman, T., Morrison, J., Poulton, C., Sibanda, L., Stevens, C., Tebele, N. and Yngstrom, I. (2003). The Impact and Poverty Reduction Implications of Foot and Mouth Disease Control in Southern Africa. International Livestock Research Institute, Nairobi.

Plantconsult (2003) Eurepgap-Introduction Among Small-Scale Producers of Fresh Fruit and Vegetables in Developing Countries. Report prepared for the Dutch Ministry of Agriculture, Ministry of Foreign Affairs, and Central Bureau for Provision Trade.Emmeloord, the Netherlands.

Reardon, T. and Berdegue, J.A. (2002). The Rapid Rise of Supermarkets in Latin America: Challenges and Opportunities for Development. Development Policy Review, 20 (4), 371-388.

Reddy, D., K. Thirumala-Devi and others (2002) Estimation of Aflatoxin Levels in Selected Foods and Feeds in India, in Food Safety Management in Developing Countries. Proceedings of the International Workshop, CIRAD-FAO, December 11-13, 2003. 
Roberts, D. (2004) The Multilateral Governance Framework for Sanitary and Phytosanitary Regulations: Challenges and Prospects. Prepared for World Bank training seminar on Standards and Trade, January 27-28, 2004. Washington, D.C.

Roberts, D. and Orden, D. Determinants of Technical Barriers to Trade: The Case of US Phytosanitary Restrictions on Mexican Avocados, 1972-1995. (1997).In: Orden, D. and Roberts, D. (eds.). Understanding Technical Barriers to Trade. International Agricultural Trade Research Consortium, University of Minnesota.

Roberts, D., T. Josling and D. Orden (1999) "A Framework for Analyzing Technical Trade Barriers in Agricultural Markets," United States Department of Agriculture, Economic Research Services. Washington, D.C.

Roberts, D., B. Krissoff (2003) The WTO Agreement on the Application of Sanitary and Phytosanitary Barriers. United States Department of Agriculture. Economic Research Service.

Roberts, D., B. Krissoff (2004) Regulatory Barriers in International Horticultural Markets, U.S. Department of Agriculture, Economic Research Service.

Salay, E. (2003) Case Study: Reducing Mycotoxins in Brazilian Crops, in Food Safety in Food Security and Food Trade, edited by L. Unnevehr, International Food Policy Research Institute, Washington, D.C.

Sumner, D.A. (ed.) (2003). Exotic Pests and Diseases: Biology and Economics for Biosecurity. Iowa State Press, Ames.

Tangthirasunan, T. (n.d.) Mycotoxin Economic Aspects. Mimeo. FAO.

Unnevehr, L. (2000) "Food Safety Issues and Fresh Food Product Exports from LDCs," Agricultural Economics 23 (2000): 231-240.

(2003) Food Safety in Food Security and Food Trade: Overview. In Food Safety in Food Security and Food Trade, edited by Unnevehr. International Food Policy Research Institute, Washington, D.C.

Unnevehr, L. and N. Hirschhorn (2001) Designing Effective Food Safety Interventions in Developing Countries. World Bank, Washington, D.C.

Weatherspoon, D.D. and Reardon, T. (2003). The Rise of Supermarkets in Africa: Implications for Agrifood Systems and the Rural Poor. Development Policy Review, 21 (3), 1-16.

Wilson, J. and T. Otsuki (2003) "Balancing Risk Reduction and Benefits from Trade in Setting Standards", in Food Safety in Food Security and Food Trade, L. Unnevehr (editor), International Food Policy Research Institute, Washington, D.C. 
Wilson, N. (2003) "A Review of Empirical Studies of the Trade and Economic Effects of Food Safety Regulations," in New Approaches to Food Safety Economics, edited by A. Velthuis and others. Boston: Kluwer Academic Publishers

World Trade Organization (2001) "Equivalence: Note by the Secretariat”, G/SPS/W/111. 